\title{
THE MYGALOMORPH SPIDER GENUS ATYPOIDES (ARANEAE: ANTRODIAETIDAE)*
}

\author{
By Frederick A. Coyle \\ Biological Laboratories, Harvard University
}

\begin{abstract}
INTRODUCTION
The genus Atypoides belongs to the mygalomorph spider family
\end{abstract} Antrodiaetidae, the remainder of which I am presently revising, and is closely related to the much larger genus Antrodiaetus. Atypoides was established by O. P.-Cambridge ( I883) with his description of Atypoides riversi. Since then two additional species have been discovered. The genus is solely Nearctic and has a markedly disjunct continental distribution, with two species in northern California and southern Oregon and one in southern Illinois and Missouri. Like the other species of antrodiaetids, those of Atypoides live in tubular silk-lined burrows in the ground and nocturnally capture prey which come within reach of the burrow entrance. In the present revision Atypoides riversi is redescribed, the two new species are described, and the geographic variation of each species is analyzed. Information on the ecology, life history, and behavior of these species will be included in a future paper treating the entire family.

Acknowledgements. I am indebted to Dr. H. W. Levi of the Museum of Comparative Zoology for encouragement and advice and to Dr. W. J. Gertsch of the American Museum of Natural History for his suggestion that I study this genus and for the large loan of A.M.N.H. material, much of which he himself has collected. Mr. J. A. Beatty, Mr. Patrick Craig, the California Academy of Sciences, and the University of Kansas have each loaned specimens. I am grateful to Prof. Varley of the University Museum of Oxford University, England, for the loan of the six syntypes of Atypoides riversi. Dr. W. H. Bossert of Harvard wrote the computer programs employed in the analysis of variation. My wife, Judy, constructed the distribution maps and helped cheerily with several other portions of the research. A National Science Foundation Graduate Fellowship and grants from the Evolutionary Biology Committee of Harvard University supported my field work during the summers of 1966 and 1967. Public Health Service Research Grant AI-org44 to Dr. Levi helped defray some expenses. Publication is supported

*Manuscript received by the editor June 12, 1968 
by a grant from the Evolutionary Biology Committee of the Department of Biology, Harvard University.

\section{Methods}

Statistical methods. An analysis of variation of quantitative characters was performed on the three species of Atypoides with two aims in mind: to discover quantitative characters of value in distinguishing between species of antrodiaetids, and to investigate in a preliminary manner the geographic variation within each species. There is greater need for such studies in mygalomorph spider taxonomy than in many araneomorph groups because of the lack of diagnostically useful complex external genitalia in the former. However, two major difficulties confront anyone attempting to study variation in mygalomorph species: the difficulty of collecting samples of adequate size, and the more difficult problem of achieving age homogeneity within samples of females. Antrodiaetid females (and females of other mygalomorph species) live and continue to molt for one to several years after becoming sexually mature. No external structure or characteristic gross difference in seminal receptacle form has been found which indicates when a female has reached sexual maturity or what instar an adult female may be.

In the present study a female specimen was included in a population sample only if it had a longer carapace than the smallest reproductively active female (with an abdomen swollen with eggs or with brood in her burrow) from the entire sample of specimens of that species. An exception was made for $A$. riversi where the smallest of a large number of reproductively active females collected in the coastal population was considerably larger than the single reproductively active Sierran population sample female. The low size limit for each of these two major population samples was therefore determined by the smallest reproductively active female within it. The non-reproductively active females included in a sample represent first adult instar females collected in the summer just before or after their initial mating, later adult instar females without broods, and probably an occasional immature female. It is likely that the small number of reproductively active females (one each) collected in the Sierran samples of $A$. riversi and in Atypoides gertschi result in samples somewhat biased toward the upper end of the actual adult female body size range.

Twenty-one measurements and I3 meristic characters were recorded for 60 males and 159 females of the three species. (The abbreviations and definitions for these measurements and meristic 
characters are given in the appendix at the end of this paper.) These data were analyzed with the aid of a 7094 IBM computer at the Harvard Computer Center. The computer program, written in Fortran II, calculated the mean and standard deviation of each measurement, meristic character, and each of 44 different ratios formed from these for each population sample of each sex and for certain groupings of samples plus individual specimens into infraspecific or species units. The program then compared these samples and groupings pairwise in all desired combinations giving for each character for each comparison a value of the distinctness of the two samples. This value, called the "distance", is equal to the difference between the mean of each of the two samples divided by the sum of their standard deviations. This enabled me to quickly select those characters of greatest diagnostic value, those characters which show the most marked geographic variation, and those infraspecific samples that were most divergent.

As will be evident in the species diagnoses and Tables I and II, many of the measurements, counts and ratios are diagnostically useful in this genus. Several measurements and counts which are not diagnostically useful are included in the tables for their descriptive value or because they are diagnostically important in Antrodiaetus, a genus in which the species are often morphologically much more similar to one another than is the case in Atypoides. The analysis of geographic variation is considered preliminary because of the small sample sizes and the lack of more samples from important parts of each species' distributional range.

Each of the localities from which a population sample of $A$. riversi or $A$. gertschi was obtained is labeled on Map I and identified in the locality records by a capital letter. These letters will be used throughout the text when referring to a particular sample or locality. The population sample sizes are indicated in the Dice-Leraas diagrams and the species sample sizes are given in Tables I and II.

Measurements. All measurements were performed by myself with the same binocular stereomicroscope and eyepiece micrometer scale. A series of three specimens was remeasured for each character five times during the course of the study and indicated that the measurements were accurate to one micrometer unit for each of the four different powers of magnification used. One micrometer unit had the following value for the following characters: $0.0753 \mathrm{~mm}$ for CL; $0.0377 \mathrm{~mm}$ for $\mathrm{CW}, \mathrm{SL}, \mathrm{SW}$, and all leg and pedipalp segment lengths; $0.0182 \mathrm{~mm}$ for PTT; and $0.0092 \mathrm{~mm}$ for CAT and all eye measurements. 
Illustrations. Drawings were made with the aid of a squared grid reticle placed in an eyepiece of a binocular stereomicroscope. Illustrations of female structures are made from reproductively active specimens or specimens much larger than the smallest reproductively active one within that species sample.

Descriptions. Each description is a composite of all the adult material at hand with close attention given to the type specimen in order to point out any characters for which it is peculiar. Colors are described in strong illumination under the low power of the stereomicroscope from a series of specimens which have been dead in $80 \%$ ethanol for six months to two years. Color changes in Atypoides appear to be minimal within this time period.

Records. Only material that has been personally examined is included within the records section. Numbers of immature specimens are not recorded; a lack of $\sigma^{\pi}$ or $q$ symbols means that only immatures were collected at that particular locality. The following abbreviations are used for the names of the more frequently cited collectors: FAC - F. A. Coyle, JWG - J. W. Gertsch, WJG W. J. Gertsch, WI - W. Ivie, VR - V. Roth.

Morphological terminology. Female genitalia: In Atypoides the sperm storage diverticulum opens into the uterus just as the latter opens exteriorly at the epigastric furrow (Figs. 78, 79). The epigastric furrow is between a large anterior lip and a smaller posterior lip. On the posterior face of the anterior lip is a more heavily sclerotized area which frames and extends inward through the transverse slit-like opening into the sperm storage diverticulum. This thickened cuticle also forms the floor of a rather large chamber which will be called the bursa copulatrix. This thickened floor often forms paired shallow depressions or ill-defined pockets which possibly function in the positioning of the male palpal sclerites. Four transparent ducts leading from the bases of the seminal receptacles open into the very weakly sclerotized roof of the bursa copulatrix. The four seminal receptacles are arranged transversely in a single row, and are thick-walled and heavily sclerotized except distally where they are capped by a rounded thin-walled transparent bulb. The proximal narrow part of the heavily sclerotized portion will be called the stalk, and the distal expanded part will be termed the bowl

Explanation of Plate 7

Figs. 1-9. Carapace and chelicerae (lateral and dorsal views). 1-3. $A$. riversi. 1-2. \& from $C$. 3. ô lectotype. 4-6. $A$. hadros. 4-5. + paratype, from type locality. 6. $\hat{o}$ holotype. 7-9. A. gertschi. 7-8. ㅇ paratype, from $O$. 9. $\hat{o}$ paratype, from $O$. 

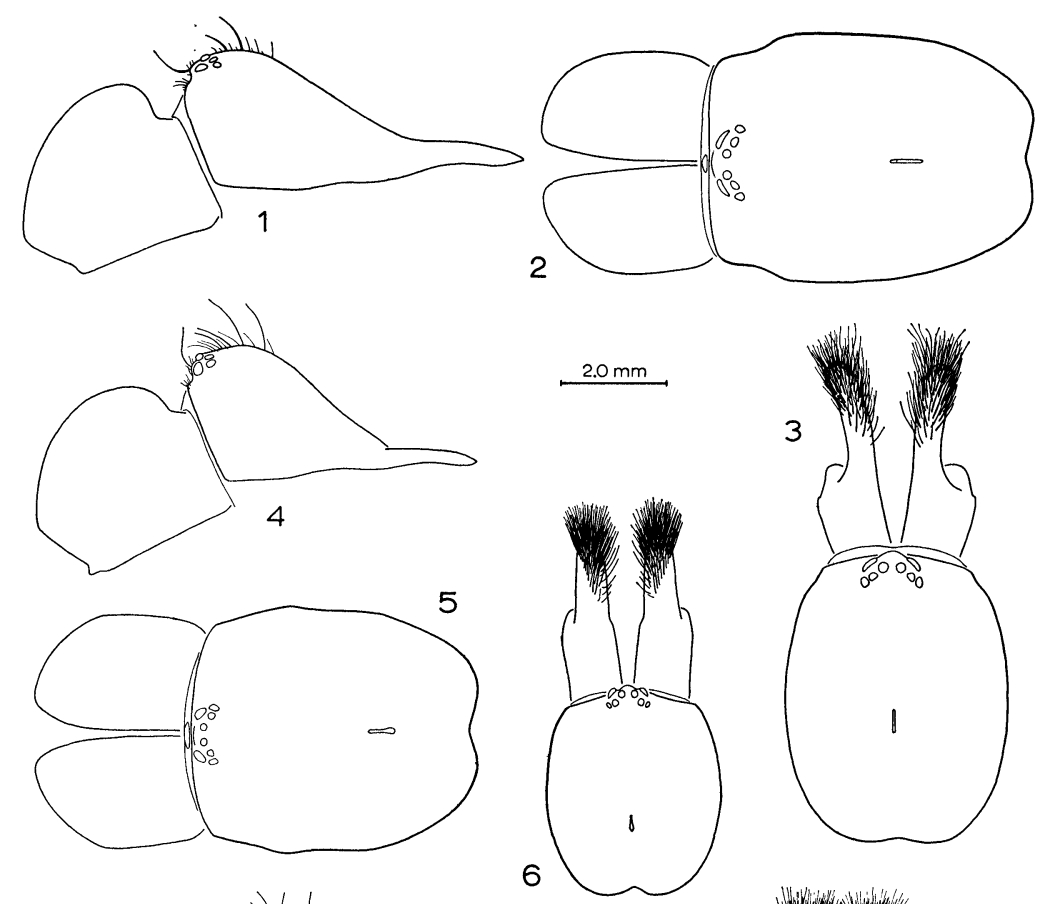

3
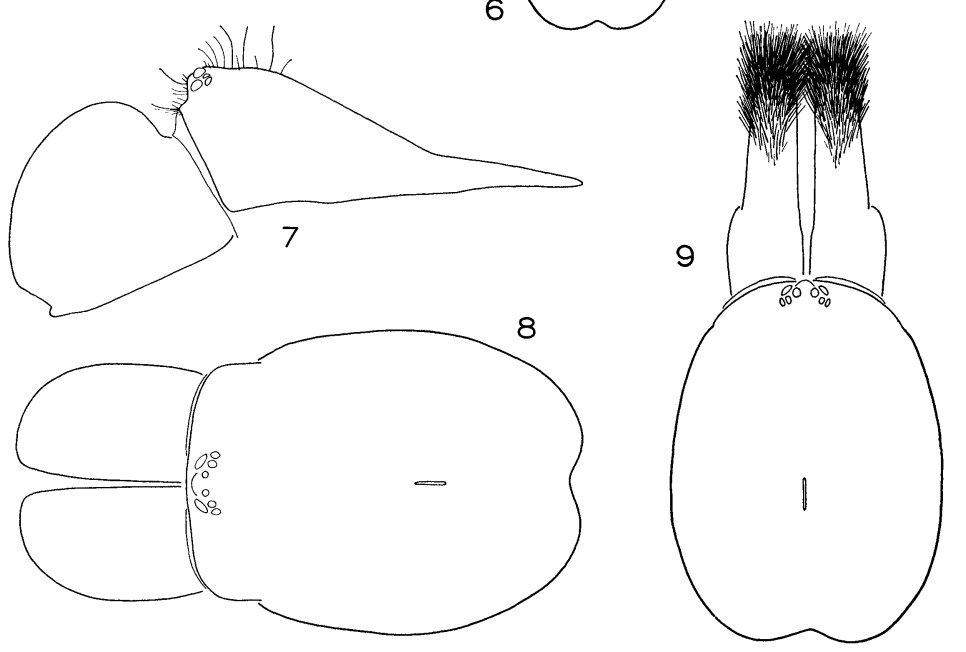

Coyle - Atypoides 
(Fig. 82). Male palpus: In Atypoides the conductor is composed of two sclerites (Fig. 57), an inner conductor sclerite, which tapers and contains the embolus distally, and an outer conductor sclerite, which lies outside and cradles the inner conductor sclerite. Macrosetae: A large thick seta, articulated in a well-developed socket, I shall call a macroseta. This is equivalent to the "spine" of most spider taxonomists. An enciform macroseta is one which tapers abruptly at its terminal end and is therefore rigid for its entire length. An attenuate macroseta is one which tapers gradually and is therefore very slender distally and easily bent. The four most lateral macrosetae on the ventral surface of the tibia in Figure $7 \mathrm{I}$ are enciform, the two median ones attenuate. Spinnerets: The abbreviations $\mathrm{AL}, \mathrm{PM}$, and $\mathrm{PL}$ will be used to designate the following spinnerets respectively: anterior lateral, posterior median, and posterior lateral.

\section{Systematics \\ Atypoides O. P.-Cambridge}

Atypoides O. P.-Cambridge, 1883, Proc. Zool. Soc. Lond., p. 354. [Type species by monotypy: $A$. riversi O. P.-Cambridge, op. cit., p. 355 , pl. 36, fig. 2.] - Simon, 1884, Bull. Soc. Zool. Fr., 9: 313, 314, 316. - Simon, 1890, Actes Soc. Linn. Bord., 44: 307, 309. - Simon, 1892, Histoire Naturelle des Araignees, pp. 193-195, fig. 138. - Smith, 1908, Ann. Ent. Soc. Amer., 1(4): 210, 211, 231. - Comstock, 1912, The Spider Book, pp. 230, 249, 250; op. cit., rev. ed., 1940, pp. 237, 238. - Gertsch, 1949, American Spiders, pp. 127, 130, 131, 265. - Bonnet, 1958, Bibliographia Araneorum, 2: 811 .

Description. Carapace: Pars cephalica elevated above pars thoracica. Thoracic groove longitudinal. Eyes: Situated on slightly raised area (more prominent in males) which is steeply inclined anteriorly. ALE largest, forming transverse or slightly procurved row with AME. Lateral limits of eye group formed by PLE. PME widely separated, close to their respective PLE. Sternum-labum: 4 pairs of sigilla; ant. pair large, just behind labium, often indistinct; post. pair larger than second or third pair. Chelicerae: Robust with strong rastellar spines in female. Single row of large teeth (macroteeth) on mesal side of closed fang; much smaller teeth (microteeth) on ectal side of post. portion of macrotooth row. Large apophysis projects anteriorly and dorsally from adult male chelicera; dense brush of large setae dorsally near distal end of apophysis. Pedipalps: Coxal endite quite small. Patella of male much shorter than tibia; tibia swollen. Outer conductor sclerite of male palpus wide, serrated on external surface, and curved in cross section so that it partially envelopes inner conductor sclerite. Distal portion of inner conductor sclerite heavily sclerotized, narrow, and envelops 
distal portion of embolus. Legs: Legs I and IV longer than legs II or III. Row of 9-26 trichobothria on dorsal surface of metatarsus IV of female. Abdomen: I-3 sclerotized areas (tergites) anteriorly on abdominal dorsum. Spinnerets: 3 pairs. AL unsegmented and reduced. PM unsegmented with functional spigots distally. PL 3 -segmented with functional spigots on second and third articles. Seminal receptacles: 4 receptacles; distinct sclerotized stalks.

Diagnosis. Atypoides may be distinguished from the genus $\mathrm{An}$ trodiaetus by each of the following two characters: I) three pairs of spinnerets (AL may be extremely reduced and difficult to spot in some specimens of $A$. gertschi). 2) Male with cheliceral apophysis. The much wider outer conductor sclerite of the male palpus of Atypoides allows separation of this genus from all known North American species of Antrodiaetus.

Atypoides may be distinguished from Aliatypus by each of the following characters: I) AL spinnerets unsegmented. 2) Male with cheliceral apophysis. 3) Patella of male pedipalp not greatly elongated. 4) Thoracic groove longitudinal. 5) Burrow entrance structure consists of a collapsible collar or a stiffened turret. 6) At least 8 or 9 trichobothria on the dorsal surface of metatarsus IV of the female. Also the structure of the male palpus in each of these two genera is distinct.

Discussion. Atypoides is closely related to Antrodiaetus. Both of these genera are much less closely related to Aliatypus. One of the two diagnostic structures separating the former two genera-AL spinnerets - is a degenerating character, and by itself would be a poor excuse for maintaining Atypoides as a separate genus. On the other hand, the cheliceral apophysis is well developed in all Atypoides males; it does not seem to be in the process of degenerating. However, it is possible that in some member (or members) of an earlier Atypoides-Antrodiaetus stock a cheliceral apophysis could have been quickly lost and its function of holding the female during mating taken over by the first legs. A consideration of the evolution of Atypoides will await the revision and similar consideration of the other antrodiaetid genera. At present it seems desirable to maintain the generic status of Atypoides, since it can be rather easily characterized and distinguished from Antrodiaetus.

Incorrect placement. Atypoides californica Banks = Aliatypus californicus (Banks). Banks ( 1896 ) described this species from an immature male specimen collected at Black Mountain, Santa Clara Co., California. Smith ( I908) discovered the adult male of this 
species and appropriately described a new genus (Aliatypus) for its placement.

\section{Key to the Species of Atypoides Males}

I. Width of sternum equal to or slightly less than its length (not including labium) (Fig. 37). Tibia I with prominent macrosetae clustered near proximal end on prolateral surface and retrolateral aspect of ventral surface; often I or 2 macrosetae near middle on ventral surface; no macrosetae at distal end of ventral surface (Figs. 71-73). Eastern U. S. (Illinois and Missouri) hadros

Sternum (not including labium) clearly longer than wide (Figs. $35,39)$. Tibia I with macrosetae present in ill-defined ventral and prolateral rows which extend most of its length; usually I to 3 macrosetae present ventrally at distal end (Figs. 68, 69, 74, 76, 77). Western U. S. (Oregon and California)

2. Palpal tibia not cylindrical, diameter in lateral view much greater at $\mathrm{I} / 3$ the distance from proximal to distal end than near distal end (Figs. IO-I3). Metatarsus I with I to 4 macrosetae on ventral surface, usually clustered at distal end (Figs. 68-70). AL spinnerets I/3 or more as long as PM (Fig. 3I). Abdomen purplish grey or purplish brown ................. riversi Palpal tibia swollen in cylindrical form of nearly equal diameter for most of its length (Fig. 15). Metatarsus I with ill-defined ventral longitudinal rows of macrosetae extending nearly its entire length (Figs. 75-77). AL spinneret $\mathrm{I} / 5$ or less (may be extremely reduced and difficult to spot) as long as PM (Fig. 30). Abdomen pale grayish yellow or pale gray

gertschi

Females

I. Sternum (not including labium) as wide as long (Fig. 38). Fewer than 13 enciform macrosetae on metatarsus I. Fewer than 7 microteeth per chelicera (Fig. 43). Wide seta-less area on ectal side of anterior portion of cheliceral macrotooth row. Eastern U. S. (Illinois and Missouri) hadros Sternum (not including labium) clearly longer than wide (Figs. 36,40 ). More than I3 enciform macrosetae on metatarsus I. Usually more than 7 microteeth per chelicera (Figs. 4I, 42). Seta-less area on ectal side of anterior portion of cheliceral macrotooth row very narrow or absent. Western U. S. (Oregon and California) 
2. AL spinnerets $\mathrm{I} / 3$ or more as long as $\mathrm{PM}$ spinnerets (Fig. 3I). Abdomen purplish gray or purplish brown. Seminal receptacles heavily sclerotized with well developed bowl (Figs. 80-86). IVML/IML $=$ I.03-I.20 ................................. riversi

AL spinnerets I $/ 6$ or less (may be extremely reduced and difficult to spot) as long as PM spinnerets (Fig. 30). Abdomen pale grayish yellow or pale gray. Seminal receptacles less heavily sclerotized with bowl weakly developed to absent (Figs. 9094.) $\quad$ IVML/IML $=$ I.34-I.45 $\ldots \ldots \ldots \ldots \ldots \ldots \ldots \ldots \ldots$ gertschi

\section{Atypoides riversi O. P.-Cambridge}

Figures I-3, IO-I3, I6, I 7, 22-29, 31, 33, 34, 39, 40, 42, 44, 45, 47-49, 53-56, 68-70, 80-86. Map I.

Atypoides riversii O. P.-Cambridge, 1883, Proc. Zool. Soc. Lond., p. 355, pl. 36, fig. 2. [Three male and three female syntypes from Berkeley, California; collected by J. J. Rivers; in the University Museum, Oxford University, England; all examined. (One of these males is here designated the lectotype and the other five specimens paralectotypes and are so labeled.) ] - Roewer, 1942, Katalog der Araneae, 1: 189.

Atypoides riversi: Simon, 1884, Bull. Soc. Zool. Fr., 9: 316. - Simon, 1892, Histoire Naturelle des Araignees, 1: 195, fig. 138. - Smith, 1908, Ann. Ent. Soc. Amer., 1(4): 209, 210, 229, pl. 15, figs. 7, 8, 9, pl. 19, fig. 2, pl. 20, figs. 3, 4. - Comstock, 1912, The Spider Book, p. 250; op. cit., rev. ed., 1940, p. 238. - Gertsch, 1949, American Spiders, p. 131. Bonnet, 1958, Bibliographia Araneorum, 2: 811.

COMMENTS ON ORIGINAL DESCRIPTION. In his description and illustrations of $A$. riversi, O. P.-Cambridge ( I883) failed to indicate the presence of a conductor on the male palpus. This misled subsequent authors (Smith, I908, and Comstock, I9I2, I940), who used the lack of a conductor as a diagnostic character for the genus. What may have misled Cambridge is that in the male syntypes the embolus has slid distally within the inner conductor sclerite, and the inner conductor sclerite has also slid distally and rotated within the outer conductor sclerite to extend far beyond it (Figs. 54, 55). A few of the $A$. riversi males which I have collected have similarly "flexed" palpi. One should be aware of the possibility of such flexion when identifying male antrodiaetids.

The lectotype and paralectotypes have changed color considerably in the 85 years since their description. The greenish hues have disappeared so that the colors are dull light oranges and orange browns.

DEscription. See Tables I, II, and III which contain measurements, meristic characters, and diagnostic ratios for a sample of the species and for the lectotype. 


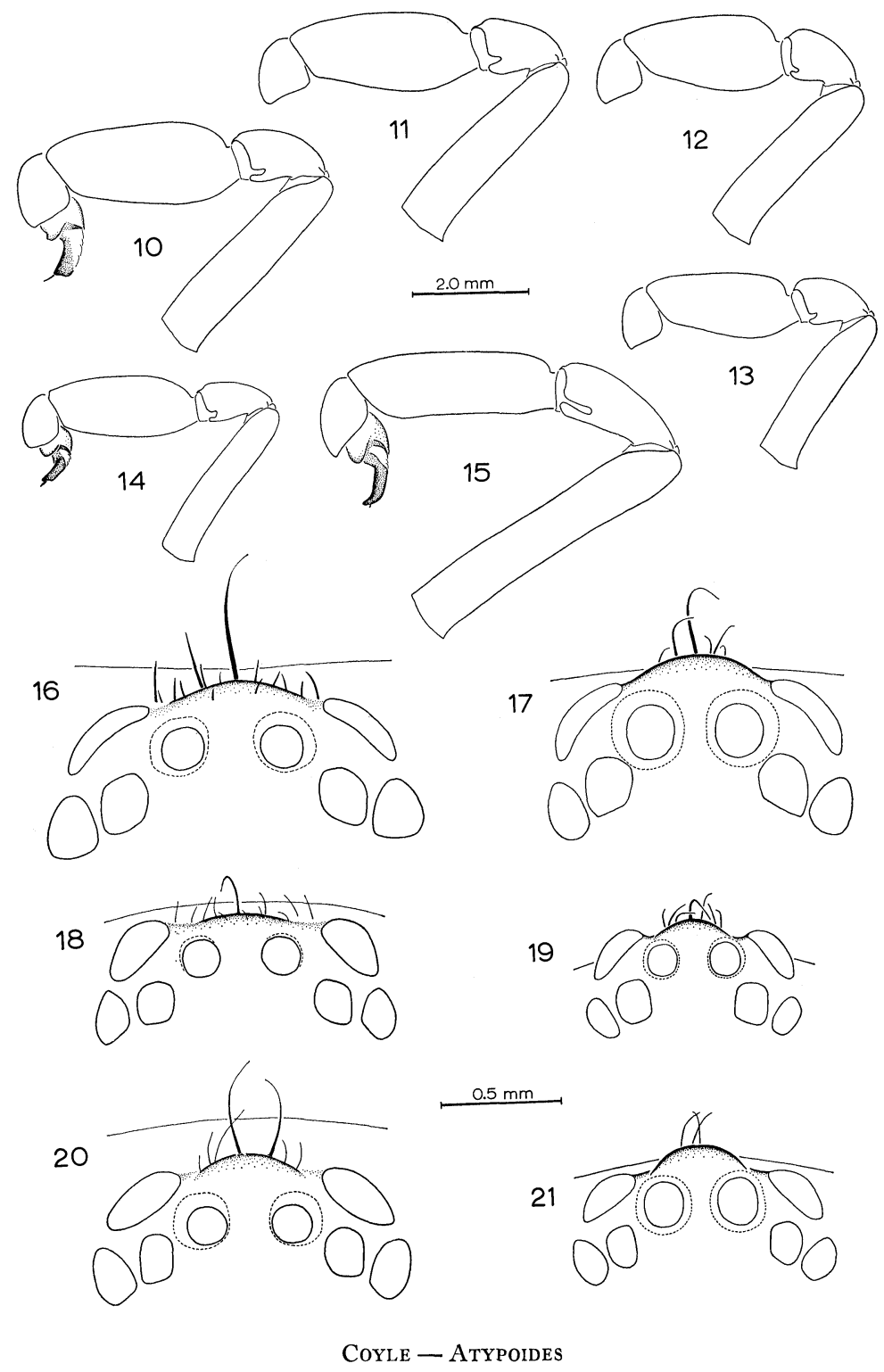


Male. Carapace: (Figs. 3, I7). Elongate oval. Thoracic groove narrow for entire length; center of thoracic groove clearly less than $2 / 3$ distance from ant. to post. border of carapace. Setae present only near edge of carapace and around eye group. Pars cephalica weakly elevated; highest at ocular protuberance. Height of clypeus at ALE about equal to vertical diam. of ALE. Diam. of AME 3/4 to 2 times their distance apart. Sternum: (Fig. 39). Elongate. 3 post. pairs of sigilla circular to oval. Chelicerae: (Figs. 3, 47-49). Apophysis relatively slender, strongly curved downward near distal end. Apophyseal setae all attenuate, post. ones stronger than ant. ones. Pedipalps: (Figs. IO-1 3, 53-56). Greatest diam. of tibia is about $\mathrm{I} / 3$ the distance from proximal to distal end; tapers to much smaller diam. distally. Outer conductor sclerite of palpus heavily sclerotized, relatively short and wide, serrations strong; tip very broad and nearly straight across. Inner conductor sclerite extends far beyond end of outer conductor sclerite in unflexed condition; distally curved and gradually tapering to rather sharp tip. Leg I: (Figs. 68-70). Tibia usually with a prolateral row and an ill-defined double or single row of macrosetae on the retrolateral aspect of the ventral surface extending most of its length; I to 3 (very rarely o) macrosetae ventrally at very distal end. Tibia nearly straight and cylindrical, curving slightly downward at distal end. Metatarsus with I to 3 macrosetae ventrally at very distal end, rarely with one on prolateral surface $\mathrm{I} / 3$ of way from proximal to distal end. Metatarsus long and slender, tapering slightly toward distal end, nearly straight in lateral view, slightly bowed in ventral view with prolateral surface concave. Abdomen: Large, median, longitudinal, tri-nodal dark pattern. Large tergite in central node. No other tergites. Spinnerets: (Fig. 3I). AL only weakly sclerotized terminally with spigot at tip, or sclerotized terminally without spigot. $\mathrm{AL} \mathrm{I} / 3$ to $\mathrm{I} / 2$ as long as PM. PM slightly expanded to unexpanded distally; maximum diam. from I/4 to slightly over I/3 length. Coloration: Pars thoracica yellowish gray to pale greenish brown. Pars cephalica pale greenish brown posteriorly, becoming brown to reddish brown an-

Explanation of Plate 8

Figs. 10-15. Male pedipalp (retrolateral view of left pedipalp), 10-13. $A$. riversi. 10. from $D$. 11. lectotype. 12. from $I$. 13. from $G$. 14. A. hadros, holotype. 15. $A$. gertschi, paratype, from $O$. [2.0 mm scale line for 10-15]

Figs. 16-21. Eyes (dorsal view with lateral border of carapace horizontal). 16-17. $A$. riversi. 16 . क from $C$. 17 . $\hat{o}$ paralectotype, from $C$. 18-19. $A$. hadros. 18. O paratype, from type locality. 19. $\hat{o}$ holotype. 20-21. A. gertschi. 20. \& paratype, from $O .21$. ô holotype. [0.5 mm scale line for 16-21] 

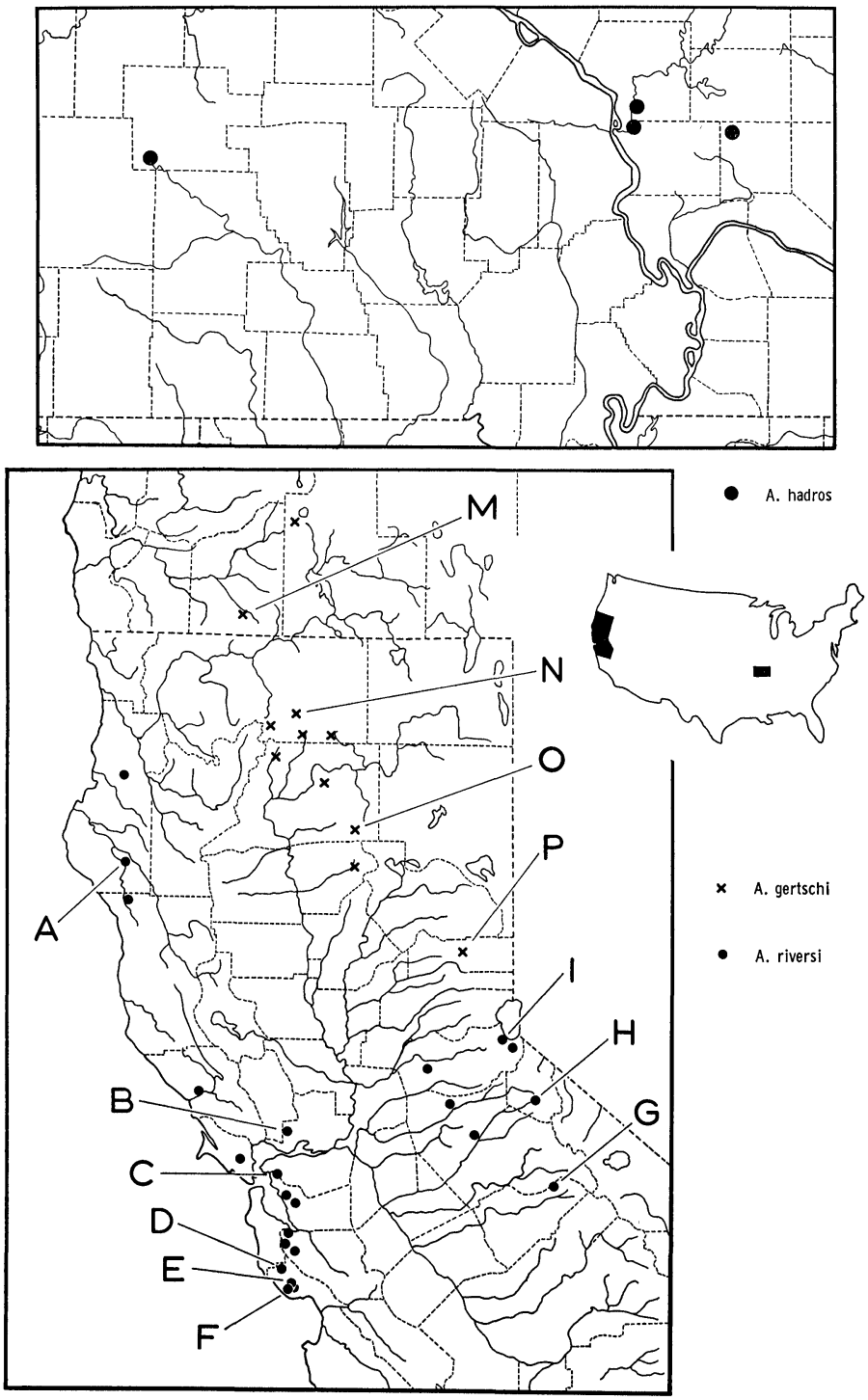

Map 1. Distribution of Atypoides species. 
teriorly. Sternum slightly paler yellnwish gray than pars thoracica, labium and palpal coxae slightly darker than pars thoracica. Chelicerae reddish brown to dark brown. Palpal femur and patella and dorsal surface of leg I light greenish brown to reddish brown; palpal tibia much lighter. Rest of legs dorsally similar to pars thoracica, ventrally lighter. Abdomen dull purplish brown with many small scattered light spots. Tri-nodal abdominal pattern a darker olive brown; tergite lighter yellowish gray.

Female. Carapace: (Figs. 1, 2, 16). Somewhat elongate; increases slightly in width from post. to near ant. end where it suddenly narrows. Shape and position of thoracic groove and distribution of setae similar to that in male. Pars cephalica usually strongly elevated, highest point just behind eye group. Height of clypeus I to 2 times vertical diameter of ALE. Diam. of AME 3/4 to I I/2 times their distance apart. Sternum: (Fig. 40). Elongate. Sigilla shape and distribution as in male. Sternal setae concentrated around edges of sternum; many stout sharply pointed ones. Chelicerae: (Figs. I, 2, 42). Dorsal protuberance prominent, post. slope steep. Microteeth positioned beside last 9 to last 3 macroteeth and usually extend beyond last macrotooth. Only a very narrow seta-less area on ectal side of ant. half of macrotooth row. Abdomen: A single tergite corresponding to tergite of central node on male abdomen. Spinnerets: (Figs. 3I, 33, 34). AL with or without spigot at tip, AL I/3 to $\mathrm{I} / 2$ as long as PM. PM slightly expanded to unexpanded distally, maximum diam. I/3 to I/2 length. Genitalia: (Figs. 8o-86). Seminal receptacles with relatively long, very heavily sclerotized, straight or slightly curved stalk; bowl strongly developed. Ant. portion of bursa copulatrix a relatively heavily sclerotized pocket which in dorsal view appears as a transverse bipartite darkened area at bases of seminal receptacles. Coloration: Pars thoracica yellowish gray to pale greenish brown. Pars cephalica darker; light brown to greenish brown. Sternum slightly lighter than pars thoracica; labium and palpal coxae slightly darker than pars cephalica. Palpal segments and legs dorsally similar to pars thoracica (except tarsi of palpi and of legs I considerably darker), lighter ventrally. Abdomen dull purplish brown, frequently darker than male abdomen, and without dark tri-nodal pattern of male; tergite yellowish gray.

DIAGNOSIS. Both sexes can be readily distinguished from the other species by their darker abdominal coloration. Males. The structure of the palpus (Figs. 53-56) and the shapes and macrosetae distribution patterns of the tibia and metatarsus of leg I (Figs. 68-70) are distinctive for this species. IML/CL and IFL/IML (Table I) 
allow separation from $A$. hadros because of the relatively long metatarsus I of $A$. riversi. The cheliceral apophysis is relatively thinner than in $A$. hadros and most specimens of $A$. gertschi (see CAT and CAT/CL, Table I). Females. The form of the seminal receptacles and bursa copulatrix aids in distinguishing this species from the others (Figs. 80-86). IVML/IML is smaller for $A$. riversi than for the others (Table II) because of the relatively short metatarsus I of $A$. hadros and the relatively long metatarsus IV of $A$. gertschi. geographic variation. Males. Comparisons of coastal population samples $(A, B, C, D, E$ and $F$ ) with one another and comparisons of Sierran population samples $(G, H$ and $I)$ with one another usually yielded smaller "distances" than coastal sample vs. Sierran sample comparisons for the same character. Sierran males are generally smaller than coastal males, but there is considerable overlap (Fig. 22). Many other measurements and meristic characters are correlated with body size and showed patterns of geographic variation similar to that of CL, but a few (IFL, IT arL, PFL and PTL) showed less or no overlap between Sierran and coastal samples (Figs. 23, 24). These appendage segments are relatively longer in the coastal samples (Fig. 23). Ratios formed of all other leg segment lengths over CL result in very wide overlap between Sierran and coastal samples. The palpal tibia is relatively more swollen in Sierran males than in coastal males (Fig. 24). Pedipalp figures IOI 3 illustrate this variation.

\section{Explanation of Plate 9}

Figs. 22-29. Geographic variation in $A$. riversi. (All measurements in $\mathrm{mm}$. For scatter diagrams solid black dots represent Sierran specimens, open dots coastal specimens, and X's the two Sierran foothills specimens.) 22-24. Males. 22. Modified Dice-Leraas diagram of CL variation. (Horizontal line represents the observed range, vertical line the mean, open rectangle the standard deviation, solid black rectangle the 95 percent confidence interval for the mean, number to right of range line the number of specimens in the sample, and letter in left column the sample-locality.) 23. Scatter diagram of IFL plotted against CL. 24. Scatter diagram of PTT plotted against PTL. 25-29. Females. 25. Mod. Dice-Leraas diagram of CL variation. 26. Histogram of CMT. (One unit of vertical scale equals a single chelicera.) 27. Mod. Dice-Leraas diagram of CMT/ICTR variation. Two dots above sample $G$ symbol represent the two Sierran foothills specimens. Top two symbols represent variation in entire coastal sample and entire Sierran sample. 28. Scatter diagram of SW plotted against CL. 29. Mod. Dice-Leraas diagram of ITL/CL variation. 

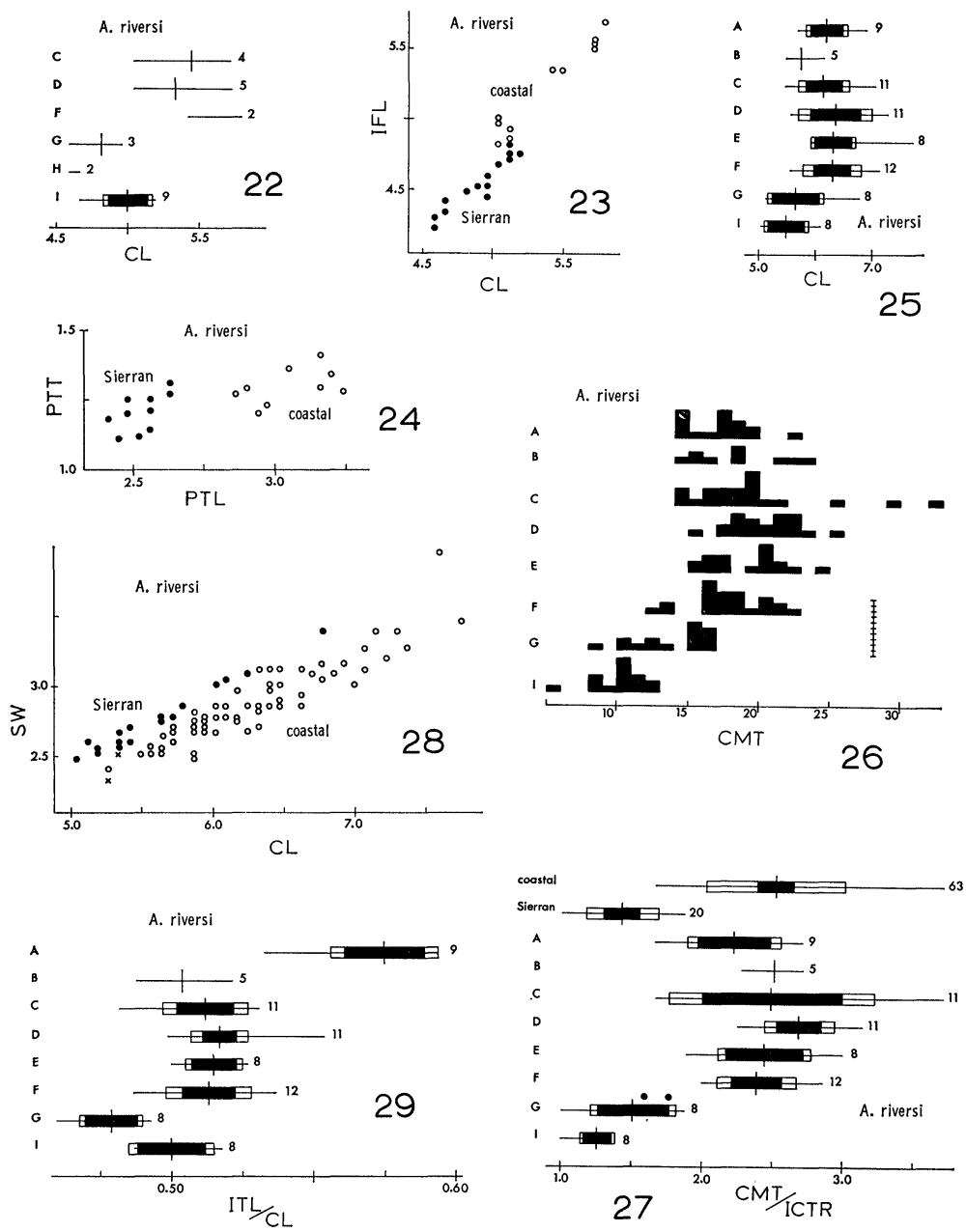

Coyle - Atypoides 
Males from $D$ and $F$ usually have thinner, straighter cheliceral apophyses which bend nearer the distal end (Fig. 48) than the apophyses of males from the type locality $C$ (Fig. 47). Some Sierran males (Fig. 49) are closer in this character to $C$ males than are the $D$ and $F$ males.

The outer conductor sclerite of the palpus of Sierran males is usually relatively shorter and wider than that of coastal males. Also, the base of the embolus (expanded portion with the looping sperm reservoir) is relatively smaller in Sierran specimens. Figures 53 and 56 are palpi representing the two extremes of geographic variation in these characters.

Most males, including all from $C, G$ and $H$, have only a single enciform macroseta ventrally at the distal end of metatarsus $I$ as in Fig. 68. The rest have either one or two additional macrosetae as in Fig. 70, and three of these specimens - all in sample $I$ - possess a single enciform macroseta on the prolateral surface one-third of the way from the proximal end. Sierran males usually have fewer tibia I macrosetae than do the coastal males.

The AL spinnerets of all coastal males possess a spigot originating from a weakly sclerotized terminus (Fig. 33). None of the Sierran males have a spigot or such a terminus on their AL spinnerets (Fig. 34). The ratio of $A L$ length to $P M$ length is usually $I: 2 I / 2$ to I:2 for coastal males and $I: 3$ to I:2 I/2 for Sierran males.

Females. As was true for the males, distances were greater in comparisons of samples of coastal females with Sierran samples than in intra-coastal or intra-Sierran comparisons. Also, CL averages somewhat less in Sierran population samples than in the coastal samples (Fig. 25). Many other measurements and meristic characters showed a similar pattern of geographic variation; a very few of these, such as CMT (Fig. 26), have small gaps between some samples. The ratio with the most marked geographic variation (with the largest distances in the paired comparisons) is CMT/ICTR (Fig. 27). The relative width of the sternum is greater for most

Explanation of Plate 10

Figs. 30-34. Spinnerets of females (ventral view). 30. A. gertschi, paratype from $O$. 31. $A$. riversi, from $C$. 32. $A$. hadros, paratype from type locality. 33-34. AL spinneret of $A$. riversi. 33. from $C$. 34 . from $G$. $[2.0 \mathrm{~mm}$ scale line for $30-32 ; 0.3 \mathrm{~mm}$ scale line for $33-34]$

Figs. 35-40. Sternum, labium, and palpal coxa (ventral view). 35-36. $A$. gertschi 35 . $\hat{o}$ holotype. 36. \& paratype, from $O$. 37-38. $A$. hadros. 37. $\hat{o}$ paratype, from type locality. 38. $ᄋ$ paratype, from type locality. 39-40. A. riversi. 39. ô lectotype. 40 . क from $C$. $[2.0 \mathrm{~mm}$ scale line for $35-40]$ 

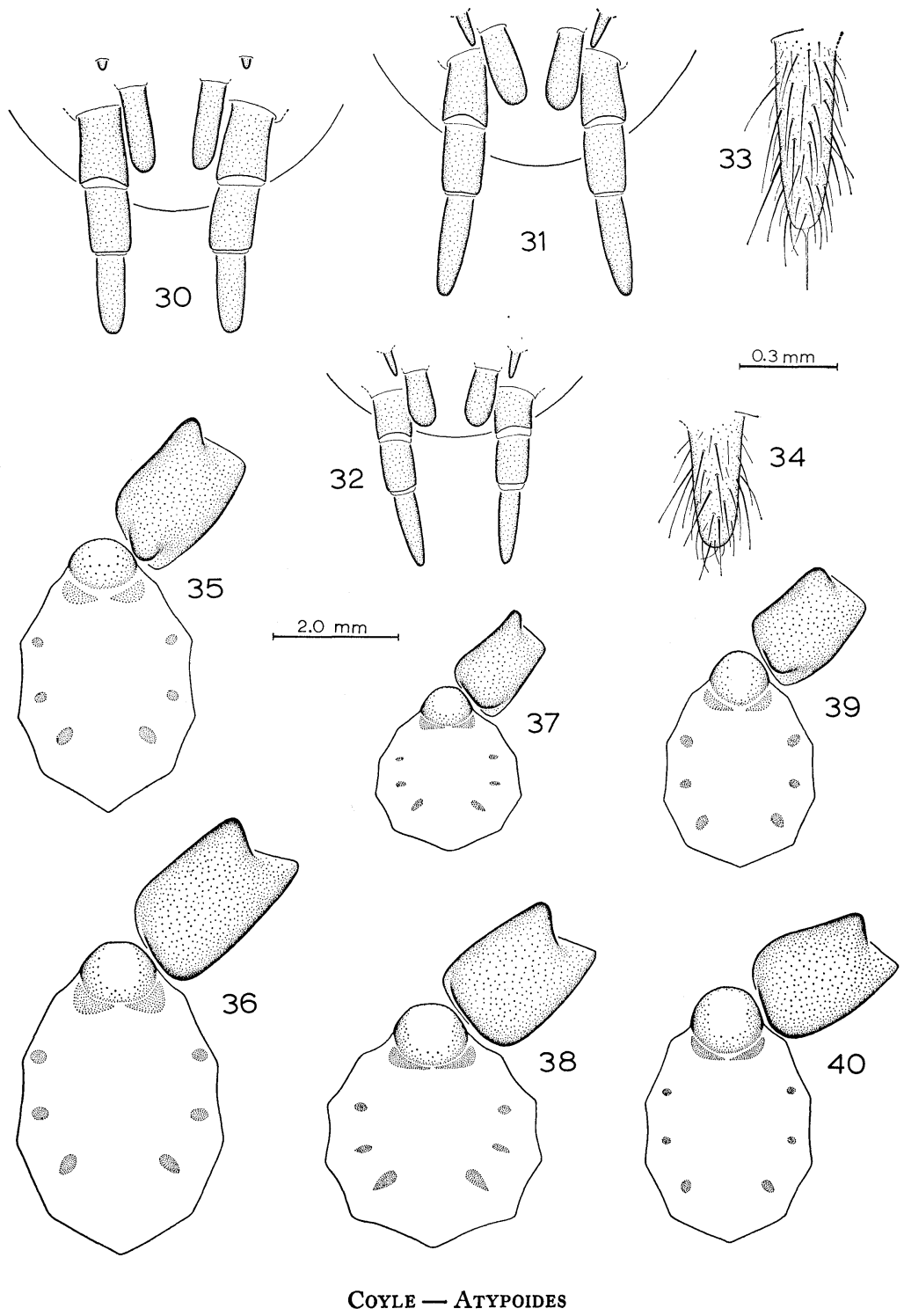
Sierran specimens than for the coastal specimens (Fig. 28). Likewise, metatarsus IV is longer relative to metatarsus $I$ than in most coastal specimens, but the overlap is greater. It is worth noting that the only two mature specimens collected low ( 2000 to $2500 \mathrm{ft}$.) in the western foothills of the Sierras are less different from the coastal populations than are most of the higher (6500 to $8000 \mathrm{ft}$.) Sierran specimens in some characters (see Figs. 27, 28). The only instance of striking intra-coastal geographic variation is the relatively long tibia I (and femur I) of sample $A$ (Fig. 29).

The ends of the AL spinnerets are sclerotized and lack spigots (Fig. 34) on all (20) Sierran females except for the two specimens collected lower in the western foothills; these each possess a single spigot on each AL spinneret. All (66) coastal females but 9 have a single spigot on each AL spinneret (Fig. 33) ; 8 of these 9 have one "normal" AL spinneret and one like the higher Sierran females, the last (from $B$ ) lacks spigots on both. The AL to PM spinneret length ratio and the shape of the PM spinnerets vary geographically as in the male samples.

The coastal populations appear to exhibit considerable intrapopulation as well as geographic variation in seminal receptacle form, so that all samples are connected by overlap. Many specimens examined resembled Figure 8I. Some have less prominent bowls (Fig. 83), or are more stout (Fig. 8o), or have a larger bowl diameter to stalk diameter ratio (Fig. 82). The Sierran specimens usually have relatively longer stalks and relatively narrower bowls (Figs. 84-86) than most coastal specimens, but there is some overlap.

DISCUSSION. The patterns of geographic variation of a number of characters indicate a considerable reduction of gene flow between the coastal population and the Sierran population. At present the Central Valley must be a formidable barrier to such gene flow, and there appears to be no contact between these populations in the more favorable montane environment to the north of the valley. It is, of course, necessary to assume that the Sierran population was once a part of (geographically continuous with and freely interbreeding with) the coastal population, possibly as recently as the more humid periods of the Pleistocene.

The important problem is whether or not sufficient isolating mechanisms have evolved since their separation to make these two populations different species. A comparison of the morphological distinctness of these two populations with the differences between any pairing of the very distinct and not too closely related species of 
Atypoides would be misleading. The genus Antrodiaetus contains two groups of quite closely related species, some sympatric and some allopatric - once Antrodiaetus is revised a comparison with the differences between its species will be more informative. Samples from lower elevations on the western slope of the Sierra Nevada Mtns. should be studied to see more clearly what variation pattern accompanies such a wide elevational (and climatic) range. A more thorough search should be made in the foothills around the northern and eastern edge of the Central Valley for additional populations. Until these approaches shed light on this problem, I feel unjustified in describing the Sierran population as a good species.

Distribution. A coastal population in northern California west of the Central Valley as far south as the Monterey Peninsula. A Sierran population, apparently geographically isolated from the coastal population, in the Sierra Nevada Mtns. and western foothills (Map I). There is no reason to doubt Rivers' ( $189 \mathrm{I}$ ) and Smith's ( I908) records of $A$. riversi from the Monterey Peninsula. Simon ( I890) lists a record of $A$. riversi from the San Bernardino Mtns. and cites George Marx for the locality data. Smith's ( I908) mention of a report of $A$. riversi from the San Bernardino Mtns. probably refers to Simon's paper. The validity of Marx's record is rather doubtful.

RECORdS. Coastal population: CALIfornia. Alameda Co.: Berkeley [sample-locality $C$ ], 3 б, 3 우 (J. J. Rivers); Oct. I919, $\sigma^{\top}$ (Dietrich); 9 ㅇ (several dates and collectors). - Castro Valley, 6 Apr. I94I, 4 + (W. M. Pearce). - Oakland, 26 Feb. I954 (R. O. Schuster, B. Adelson). - Humboldt Co.: I $8 \mathrm{mi}$. W. of Willow Creek, 2 I Aug. I959, 2 ㅇ․ - Miranda [sample-locality $A$ ], 3 June I936, 9 ㅇ (C. R. Crosby). - Marin Co.: San Geronimo, 27 Sept. I963, \& (WI). - Mendocino Co.: Christine, 30 May I936, ㅇ. - Piercy, 23 July I953 (WJG, JWG). — Santa Clara Co.: Black Mtn. (R. W. Doane). - Stanford Univ. campus, Feb. I92 I (J. C. Chamberlin). - Stevens Creek, 20 Apr. I94I, 2 ㅇ (W. M. Pearce). - Santa Cruz Co.: Ben Lomond [sample-locality $E$ ], 25 June I952, 3 우 (WJG) ; 20 July 1953, 3 우 (WJG) ; 3 Apr. I960, 2 ㅇ (WJG, WI, Schrammel); 28 March ig2 I, $q$ (O. E. Sette). - Felton, i6 Aug. I959, o (VR, WJG). - 7 mi. N.W. of Santa Cruz on Empire Grade Rd., 23 June 1965 , o (H. B. Leech). 2 to $5 \mathrm{mi}$. W. of Felton on Ice Cream Grade Rd. [sample-locality $F$ ], IOOO-I $700 \mathrm{ft}$., I 4 Aug. 1967, $20^{\pi}$, I I $ᄋ$ (FAC). - $.6 \mathrm{mi}$. and 4.O mi. N. of Big Basin St. Pk. headqtrs. on Big Basin Highway [sample-locality $D$ ], I 500 and I750 ft., I 5 Aug. I967, 5 o, I2 웅 
(FAC). - Solano Co.: Green Valley Creek [sample-locality B], I9 June 1953, 5 ㅇ (E. I. Schlinger). — Sonoma Co.: Guerneville, 22 July i953, 3 + (WJG, JWG).

Sierran population: CALIFornia. Alpine Co.: Ebbets Pass [sample-locality $H$ ], $8730 \mathrm{ft} .$, I9 Sept. I963, $\mathrm{o}^{\pi}$ (WJG). - $5 \mathrm{mi}$. W. of Ebbets Pass on Rt. 4 [sample-locality $H$ ], 7500 ft., 7-8 Aug. 1967, ot, o (FAC). - Amador Co.: Pine Grove, 2500 ft., 7 July 1958, \& (WJG, VR). - Calavaras Co.: Avery, 8 July I958 (WJG, VR). - El Dorado Co.: Meyers, 6500 ft., 5 Sept. 1958, ㅇ (E. I. Schlinger). $-3 \mathrm{mi}$. N. of Placerville, $2000 \mathrm{ft}$., 8 Sept. 1959, ㅇ (WJG, VR). - Bayview Campground (U.S.F.S.) at Emerald Bay of L.' Tahoe [sample-locality I], 6500 ft., 6-7 Aug. I967, $90^{\pi}, 8$ o (FAC). - Mariposa Co.: Yosemite Natl. Pk., about 20 mi. E. of Crane Flat on Rt. 120 [sample-locality $G$ ], 8000 ft., 8 Aug. 1967, 3 o, 8 ㅇ (FAC).

\section{Atypoides gertschi new species}

Figures 7-9, 15, 20, 21, 30, 35, 36, 4I, 50-52, 58-60, 6I-67, 74-77, 90-94. Map I.

TYPE SPECIMENS. Holotype male from Manzanita Lake, $5890 \mathrm{ft}$. ( $790 \mathrm{~m}$ ), Lassen Volcanic National Park, Shasta Co., California, 3 August 1967 (F. A. Coyle) in the Museum of Comparative Zoology. Four males and 12 females from type locality with same data (except 2 of the females collected 5 July 1952 by W. J. Gertsch) designated as paratypes and deposited in the M.C.Z. and A.M.N.H. This species is named in honor of Dr. W. J. Gertsch for his valuable contributions to the systematics of the atypoid mygalomorphs and in appreciation of his help.

DESCRIPTION. See Tables I, II and III which contain measurements, meristic characters, and diagnostic ratios for a sample of the species and for the holotype.

\section{Explanation of Plate 11}

Figs 41-43. Cheliceral teeth of females (ventral view of left chelicera). 41. A. gertschi, paratype, from $O$. 42. A. riversi, from $D$. 43. $A$. hadros, paratype, from type locality. [1.0 $\mathrm{mm}$ scale line for 41-43.]

Figs. 44-45. Left palpal tarsus of $A$. riversi (retrolateral aspect of dorsal surface). 44. + , from $D$. 45. penultimate $\hat{o}$, from $F \cdot[2.0 \mathrm{~mm}$ scale line for 44-45.]

Figs. 46-52. Chelicerae of males (ectal view of dissected left chelicera without fang). 46. $A$. hadros, holotype. 47-49. $A$. riversi. 47. lectotype. 48. from $F$. 49. from $I$. 50-52. $A$. gertschi. 50. from $P$. 51. paratype, from $O$. 52. from $M$. [2.0 $\mathrm{mm}$ scale line for 46-52] 
Psyche, 1968

Vol. 75, Plate 11
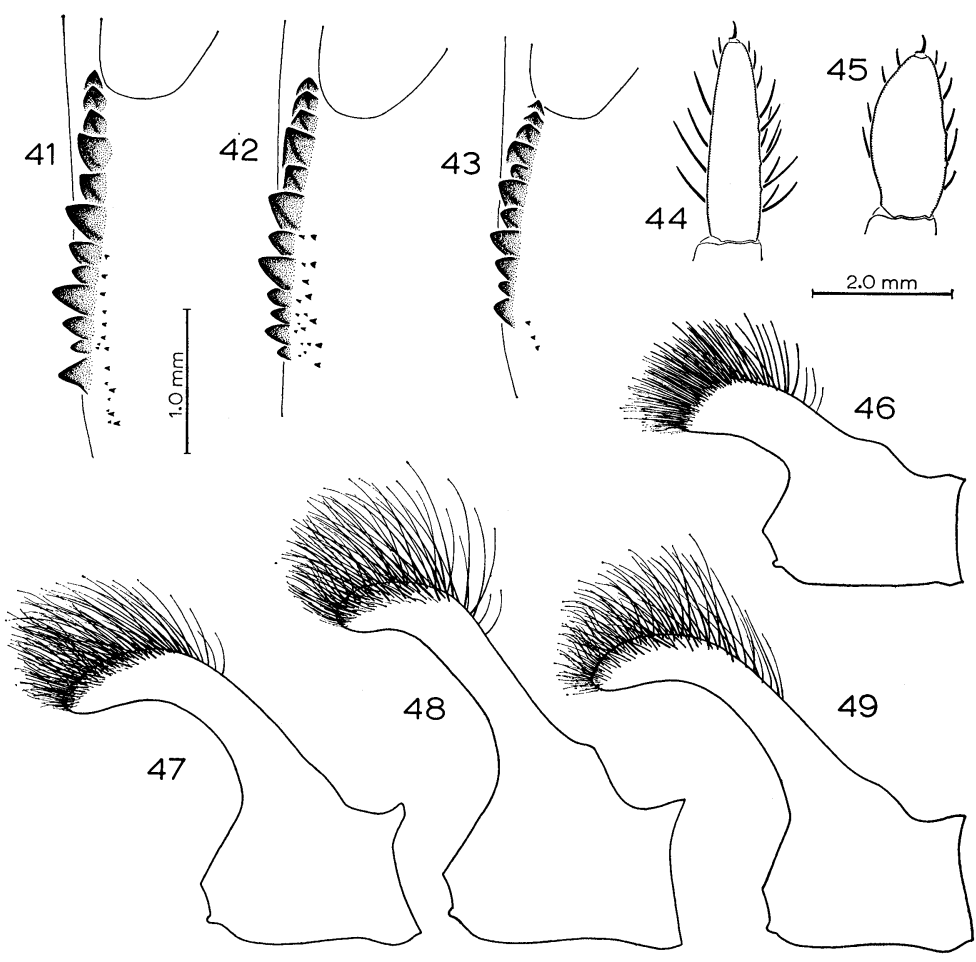

$2.0 \mathrm{~mm}$

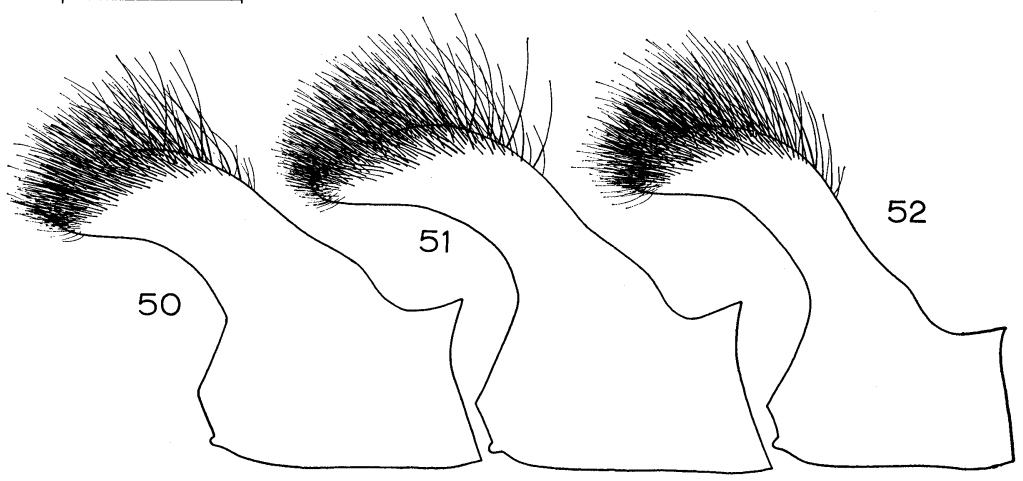

Coyle - Atypoides 
Male. Carapace: (Figs. 9, 2I ). Elongate oval. Thoracic groove narrow for entire length; center of thoracic groove less than $2 / 3$ distance from ant. to post. border of carapace. Setae scattered over entire pars thoracica, densest at lateral edges. Setae rare to absent at base of pars cephalica, becoming numerous higher up. Pars cephalica weakly elevated, highest at eye group. Height of clypeus at ALE I to I I/2 times vertical diam. of ALE. Diam. of AME 2/3 to slightly greater than their distance apart. Sternum: (Fig. 35). Elongate. 3 post. pairs of sigilla oval. Chelicerae: (Figs. 9, 50-52). Apophysis moderately to very thick; curving downward distally. All apophyseal setae attenuate, post. ones stronger than ant. ones. Pedipalps: (Figs. 15, 58-60). Tibia swollen in cylindrical form, of nearly equal diam. for most of its length. Outer conductor sclerite of palpus long, translucent, serrations small; tip rounded to pointed. Inner conductor sclerite extends slightly to well beyond edge of outer conductor sclerite; narrowed and slightly curved distally, rather blunt at tip. Leg I: (Figs. 74-77). Tibia with 3 ill-defined longitudinal rows of macrosetae (I prolateral and 2 ventral) running most of its length. Tibia nearly straight and cylindrical, curving downward slightly at distal end. Metatarsus with 2 ill-defined longitudinal lateroventral rows of macrosetae extending most of its length. Metatarsus nearly straight, decreasing gradually in diam. toward distal end. Abdomen: 2 large tergites, second slightly larger than first; often a bilateral pair of tiny sclerotized spots post. to second tergite. Spinnerets: (Fig. 30). AL greatly reduced; lacking spigots; not more than $\mathrm{I} / 5$ as long as $\mathrm{PM}$, often much less. PM elongate and cylindrical; diam. I/4 to I/3 length. Coloration: Pars thoracica pale yellow to grayish orange. Pars cephalica light brown to brown. Sternum slightly lighter than pars thoracica; labium and palpal coxae slightly lighter than pars cephalica. Chelicerae light brown to dark reddish brown. Palpal femur and patella grayish orange to dark orange brown, tibia and tarsus slightly lighter. Leg I dorsally nearly as dark as palpal femur; rest of legs lighter dorsally, slightly darker than pars thoracica. Abdomen light grayish yellow to light gray; tergites darker yellowish gray. Holotype nearer to darker end of color range.

Explanation of Plate 12

Figs. 53-60. Palpus (prolateral view of left palpus). 53-56. A. riversi. 53. from $D$. 54-55. Lectotype, in "flexed" condition. 54. ventral view. 55. prolateral view. 56. from $G$. 57. $A$. hadros, holotype (o.c.s. - outer conductor sclerite, i.c.s. - inner conductor sclerite, emb. - embolus). 58-60. $A$. gertschi. 58. holotype. 59. from $N$. 60. from $M$. 


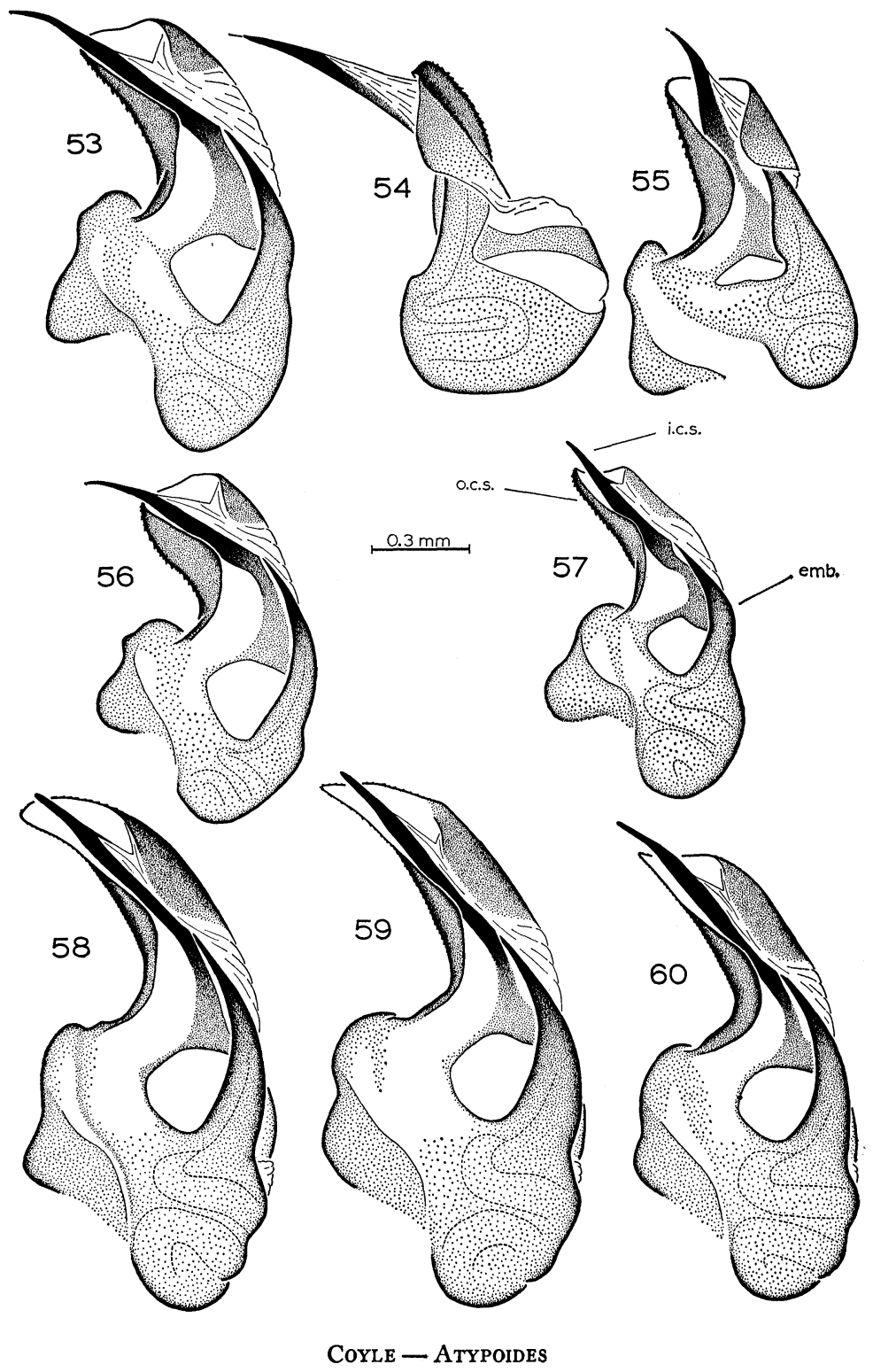


Female. Carapace: (Figs. 7, 8, 20). Lateral border rounded in dorsal view, widest at or behind center; somewhat constricted at ant. portion of pars cephalica. Shape and position of thoracic groove and distribution of setae similar to that in male. Pars cephalica moderately elevated, highest either at eye group or slightly behind. Height of clypeus at ALE I to 2 times vertical diam. of ALE. Diam. of AME I to 2 times their distance apart. Sternum: (Fig. 36). Elongate. Shape and position of sigilla as in male. Sternal setae all slender. Chelicerae: (Figs. 7, 8, 4I). Dorsal protuberance broadly rounded in side view. Microteeth positioned beside last 7 to last 3 macroteeth; often extend beyond last macrotooth. No seta-less area on ectal side of ant. half of macrotooth row. Abdomen: Single tergite corresponding to second tergite on male. Group of prominent setae ant. to tergite, sometimes with small patches of sclerotized cuticle at their bases, corresponding with first tergite on male. Spinnerets: (Fig. 30). AL greatly reduced; lacking spigots; not more than $I / 7$ as long as PM, often much less. PM as in males. Genitalia: (Figs. 90-94). Seminal receptacles relatively weakly sclerotized; stalks strongly sinuous to stouter and non-sinuous; bowl very weakly developed, its border with bulb ill-defined. Coloration: Pars cephalica pale yellow to light grayish orange; pars thoracica the same or slightly paler. Sternum same as pars cephalica; labium and palpal coxae slightly darker. Chelicerae pale grayish orange to orange brown. Pedipalps and legs dorsally similar to pars cephalica, ventrally slightly lighter. Abdomen similar to male; tergite usually lighter than male tergites.

DIAGNosis. Both sexes of $A$. gertschi can be separated from the other species by the greatly reduced AL spinnerets which are I/5 or less as long as the PM spinnerets and by the setae scattered over the pars thoracica. Also, the relatively small size of the eye group and the AME allow separation from the other species by OQW/CL and CL/AMD (Tables I and II). Males. The structure of the palpus (Figs. 58-60) and the shapes and macrosetae distribution patterns of the tibia and metatarsus of leg I (Figs. 74-77) are distinctive

\section{Explanation of Plate 13}

Figs. 61-67. Geographic variation in $A$. gertschi. (All measurements in $\mathrm{mm}$. For scatter diagrams solid black dots represent $P$ specimens, $X$ 's represent $M$ specimens.) 61-63. Males. 61. Mod. Dice-Leraas diagram of CL variation. 62. Scatter diagram of ITarL plotted against CL. 63. Scatter diagram of IML plotted against CL. 64-67. Females. 64. Histogram of ICTR. (One unit of vertical scale represents a single specimen.) 65. Histogram of CT. (One unit of vertical scale represents a single chelicera.) 66. Mod. Dice-Leraas diagram of CT/ICTR variation. 67. Scatter diagram of IVTL plotted against CL. 

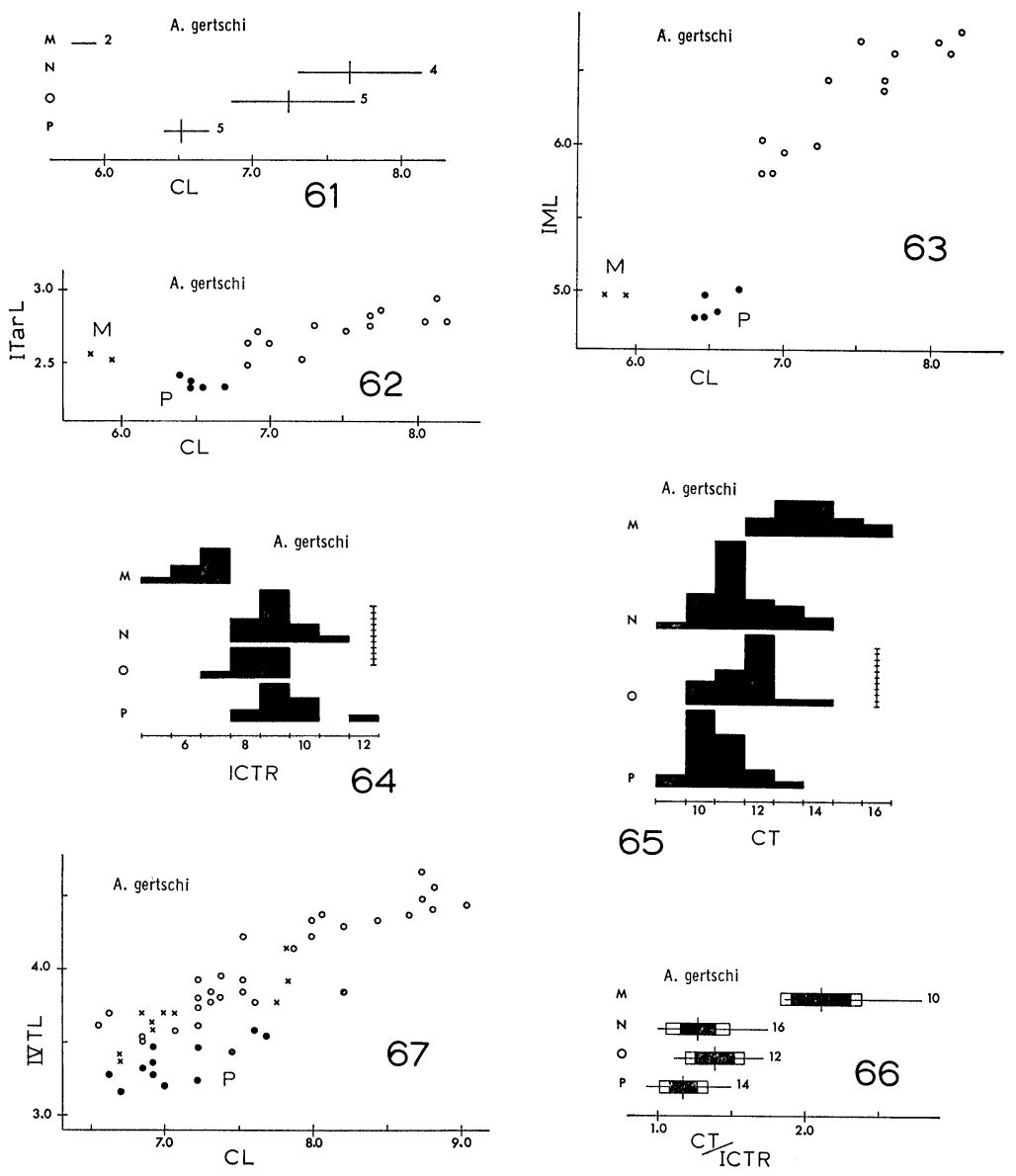

Coyle - Atypoides 
for this species. The shape of the palpal tibia (Fig. 15) is an excellent distinguishing character and is quantified by the ratios PTT/CL and PTT/PTL (Table I). Because of the relatvely long metatarsus IV and short tarsus IV of $A$. gertschi, separation from the other two species is aided by IVML/IML and IVML/IVTarL (Table I) and from $A$. riversi by IVTarL/CL (Table I). Because of the large body size of $A$. gertschi, IVML, PFL, and even CL will help in identification.

GEOGRAPHIC VARIATION. Males. $M$ is the most divergent population sample and $P$ the next most divergent in most of the characters studied. CL (Fig. 6I) and almost all other measurements and meristic characters correlated with body size were much smaller in the two $M$ specimens than in the other males. The greatest distance between sample $M$ and the other samples occurs with the ratio ITarL/CL (Fig. 62) and other ratios expressing the relatively long tarsus $\mathrm{I}$ in these two specimens. Sample $P$ has strikingly smaller values of IML/CL than the other males of $A$. gertschi (Fig. 63). Most of the other ratios yield smaller distances between populations than the measurements and meristic characters.

CAT varies considerably within samples $N, O$ and $P$, but averages thicker in $P$, and thinner in $M$, than in $N$ and $O$, so that there is a north to south cline of increasing CAT diameter. Figure 52 is a cheliceral apophysis from $M$ near the lower end of the range of variation, Figure 5I is an apophysis from $O$ near the middle of the CAT range, and Figure 50 is an apophysis from $P$ near the maximum CAT. The geographic variation pattern of the ratio CAT/CL is less clinal and shows much overlap.

The tip of the outer conductor sclerite is rounded in the holotype (Fig. 58) and in all other males except two of sample $N$ (from $6700 \mathrm{ft}$. near Sand Flat Rd.) with considerably more pointed tips (Fig. 59) and both males from $M$ with strongly pointed tips (Fig. $60)$. The distance which the inner conductor sclerite extends beyond the end of the outer conductor sclerite varies considerably within most samples, but is longest in the $M$ males. This latter variation may not be genetic, but rather due to palpal flexion prior to death.

Intrapopulation variation in the number of enciform macrosetae on the tibia (range for all specimens is $13-18$ ) and metatarsus (range for all specimens is 9-24) of leg I is large, and all population samples are connected by wide overlap. Figure 75 shows a metatarsus I with relatively few enciform macrosetae and Figure 74 shows a tibia with a larger number than the holotype (Fig. 76). 
Most of the sample $P$ specimens, both from $M$, and a few other individuals have AL spinnerets which are reduced to nearly imperceptable swellings marked by two or three crooked setae. Other specimens have AL spinnerets intermediate in size between these and those in samples $N$ and $O$ which are usually I/6 to I/5 as long as the PM spinnerets.

Females. As in the male sample comparisons, $M$ is the most divergent and $P$ the next most divergent sample of females. Wide overlap exists among all four population samples in almost every character. For measurements and meristic characters, the greatest interpopulation "distances" show up in ICTR (Fig. 64), IVCTP, IVCTR, and CT (Fig. 65) in each of which sample $M$ is divergent. The only ratios with strong geographic variation are CT/ICTR (Fig. 66), which produces a gap between sample $M$ and the others, and IVTL/CL (Fig. 67) and IVML/CL both of which separate sample $P$ somewhat from the other samples.

The setation of the carapace and chelicerae of females (and males) from $M$ and from Ney Springs, Siskiyou Co., Calif., is sparcer than on most specimens from other localities. The dorsal protuberance of the chelicerae in side view is slightly higher and less broadly rounded in most females of sample $M$. The AL spinnerets of several specimens from $P$ and one from $M$ are greatly reduced as described above for the males. Sample $O$ has the highest mean AL spinneret length, $N$ and $M$ the next highest.

The seminal receptacles exhibit wide variation in shape. Samples $N$ and $O$ and a small sample from Crater Lake Natl. Park have widely overlapping ranges, with stalks usually quite sinuous (Figs. 90-92). Population sample $P$ differs markedly from these samples, with nearly non-sinuous to slightly sinuous and short stalks (Fig. 94). $M$ also differs, usually with nearly non-sinuous and stout stalks (Fig. 93).

DISCUSSION. These patterns of geographic variation may be the result of reduced interpopulation gene flow at the periphery of the species range and consequent divergence of certain peripheral populations $(M$ and $P)$. Population $M$ appears to be near the northwestern periphery of the species range and is much lower in elevation and in a somewhat different habitat than the other three population samples. Population $P$ is near the southern edge of the species range. Larger sample sizes (particularly of males) and geographically intermediate samples are needed to clarify the status of these two populations. The possibility that isolating mechanisms have evolved 
between $M$ and the other populations studied should be emphasized, but on the basis of the present incomplete data I feel unjustified in assigning a subspecific or specific status to the population represented by sample $M$.

Distribution. Cascade Mtn. Range and foothills from southern Oregon south and east into the northern end of the Sierra Nevada Mtns. of California (Map I).

ReCords. California. Shasta Co.: $8 \mathrm{mi}$. S. Dunsmuir, i I July 1954 (R. O. Schuster, E. E. Gilbert). - Hatchet Creek, Io mi. W. of Burney, I Aug. I953 (WJG, JWG). - Lassen Vol. Natl. Pk., Manzanita Lake [sample-locality $O$ ], 5890 ft., 3-4 Aug. I967, $50^{x}$, Io 9 (FAC); 5 July I952, 2 早 (WJG). - Sierra Co.: Yuba Pass [sample-locality $P$ ], $6700 \mathrm{ft} ., 5$ Aug. I967, $50^{x}$, I4 우 (FAC). $-3 \mathrm{mi}$. W. of Yuba Pass, $6200 \mathrm{ft}$., 5 Aug. I967 (FAC). — Siskiyou Co.: Bartle, 2 I July I94I, 0 (W. M. Pearce). - Ney Springs, 5 mi. W. of Mt. Shasta City, I2 Sept. I959, 2 o (WJG, VR). - 5 mi. E. of McCloud on Rt. 89 along McCloud Cr., I Aug. 1967 (FAC). - 5 to $14 \mathrm{mi}$. E. of Mt. Shasta City on Rt. Aio [sample-locality N], I-2 Aug. I967 (McBride Springs, 4950 ft., o; 5700 ft., + ; Sand Flat Rd., 6700 ft., $20^{\top}, 4$ \% ; Panther Meadows Campgrd., $7440 \mathrm{ft} ., 20^{x}$, I I 9$)$, (FAC). - Tehama Co.: Deer Creek, 6 July 1952, 2 ot (WJG). oregon. Jackson Co.: Ashland, Lithia Park, 2000 ft., [sample-locality $M$ ], 3I Aug. 1959, $2 \sigma^{\pi}$, 9 우 (WJG, VR); 31 July 1967, ㅇ (FAC). — Klamath Co.: Crater L. Natl. Pk., Annie Springs Campground, 6000 ft., 24 Aug. 1956, ơ (R. W. Fredrickson); 30 July 1967, o (FAC).

\section{Atypoides hadros new species}

Figures 4-6, 14, 18, 19, 32, 37, 38, 43, 46, 57, 71-73, 78, 79, 87-89. Map I.

TYPE SPecimens. Holotype male from Ferne Clyffe State Park, Johnson Co., Illinois, I3 September r966 (F. A. Coyle) in the Museum of Comparative Zoology. One male and 4 females from type locality with same date designated as paratypes and deposited

\section{Explanation of Plate 14}

Figs. 68-77. Male leg I tibia and metatarsus (left leg). 68-70. $A$. riversi, from $D$. 68. ventral view. 69. prolateral view. 70 . ventral view of distal end of metatarsus; another specimen. 71-72. $A$. hadros, holotype. 71. ventral view. 72. prolateral view. 73. $A$. hadros, from Pine Hills, Union Co., Ill.; ventral view of tibia. 74-77. $A$. gertschi. 74. paratype, from $O$, ventral view of tibia. 75. from $M$, ventral view of metatarsus. 76. holotype, ventral view. 77. holotype, prolateral view. 

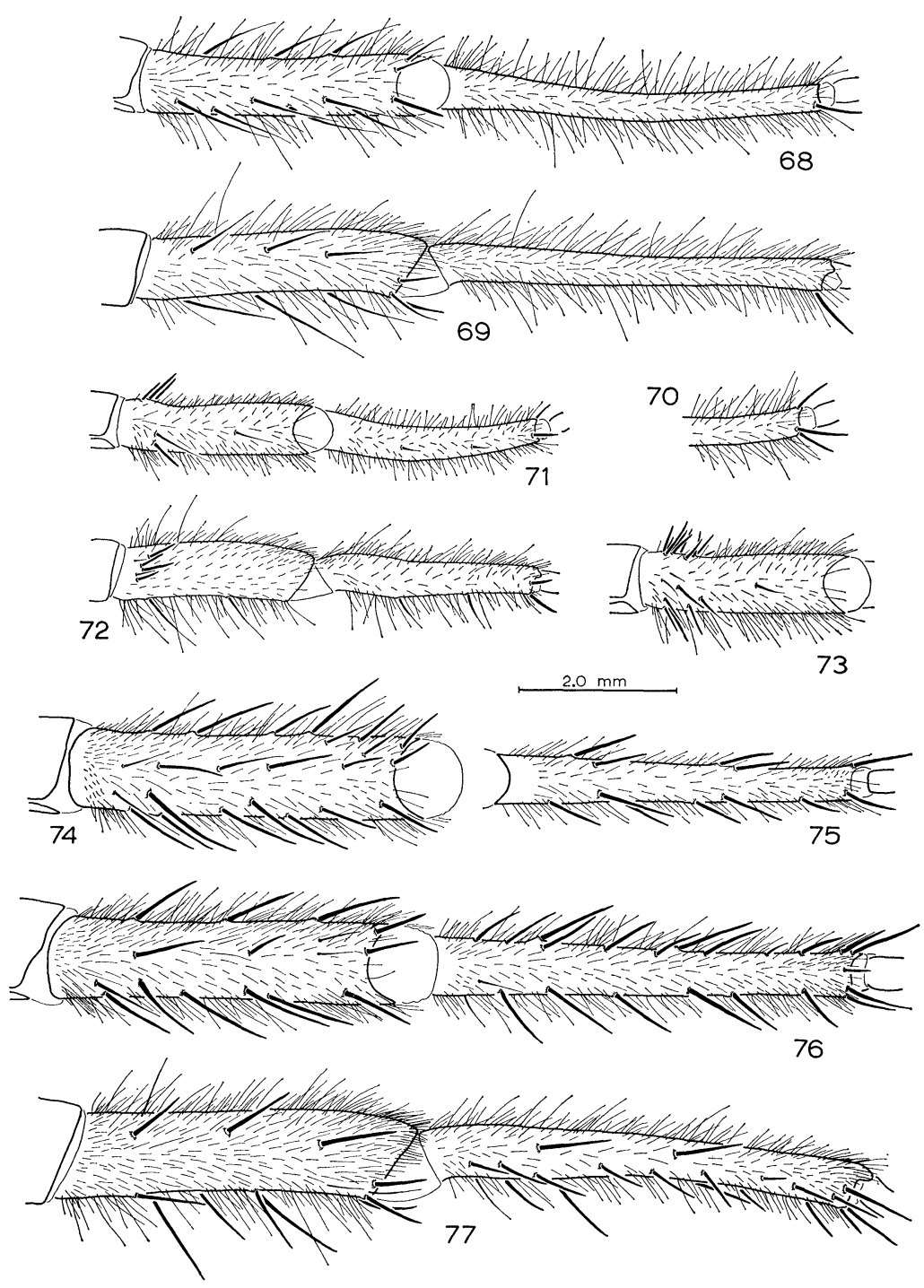

COYle - Atypoides 
in the M.C.Z. and the A.M.N.H. Hadros is a Greek adjective meaning "stout" or "thick".

Description. See Tables I, II, and III which contain measurements, meristic characters and diagnostic ratios for a sample of the species and for the holotype.

Male. Carapace: (Figs. 6, 19). Quite broad. Post. part of thoracic groove expanded laterally; center of thoracic groove about $2 / 3$ distance from ant. to post. border of carapace. Setae present only near edge of carapace and around eye group. Pars cephalica moderately elevated; highest anteriorly at eye group. Height of clypeus at ALE much less than vertical diam. of ALE. Diam. of AME slightly greater than their distance apart. Sternum: (Fig. 37). Nearly as wide as long. 3 post. pairs of sigilla oval, 2 posterior-most pairs usually drawn out and tapered toward edge of sternum, post. pair most drawn out. Chelicerae: (Figs. 9, 46). Apophysis thick and short, weakly curved downward distally. Apophyseal setae strong, post. ones non-attenuate and stiff. Pedipalps: (Figs. I4, 57). Tibia with greatest diam. in lateral view about $\mathrm{I} / 3$ the distance from proximal to distal end, tapering to much smaller diam. distally. Outer conductor sclerite of palpus heavily sclerotized, serrations strong, end concave with one side extending beyond other. Inner conductor sclerite extends well beyond end of outer conductor sclerite in unflexed condition; distally tapering, only slightly curved and relatively thick. Leg I: (Figs. 7I-73). Tibia with group of mostly enciform macrosetae at proximal end on prolateral surface, a smaller group (sometimes only I) of macrosetae proximally on retrolateral aspect of ventral surface and I (rarely o or 2) macroseta near middle ventrally. Tibia nearly cylindrical, curving downward slightly at distal end; swollen slightly at proximal groups of macrosetae.

\section{Explanation of Plate 15}

Figs. 78-79. Female genital region, $A$. hadros, paratype, from type locality. 78. Semidiagrammatic long. section through a median seminal receptacle, ant. and post. lips slightly pulled apart. 79. Posterior ventral view of genital region. (a.1. - anterior lip, p.l. - posterior lip, b.cop. bursa copulatrix, o.b.cop. - opening of the b.cop., ut. - uterus, sem.r. seminal receptacle) [0.5 mm scale line for 79$]$

Figs. 80-94. Seminal receptacles (dorsal view). 80-86. A. riversi. 80. from $D$. 81. from $C$. 82. from San Geronimo, Marin Co., Calif. 83. from Guerneville, Sonoma Co., Calif. 84. from Placerville, El Dorado Co., Calif. 85. from $I$. 86. from $G$. 87-89. $A$. hadros. 87-88. paratypes, from type locality. 89. from Little Grand Canyon, Jackson Co., Ill. 90-94. A. gertschi. 90. paratype, from $O$. 91. from Crater L. Natl. Pk., Klamath Co., Ore. 92. from $N$. 93. from $M$. 94. from $P$. [0.5 $\mathrm{mm}$ scale line for $80-94]$ 

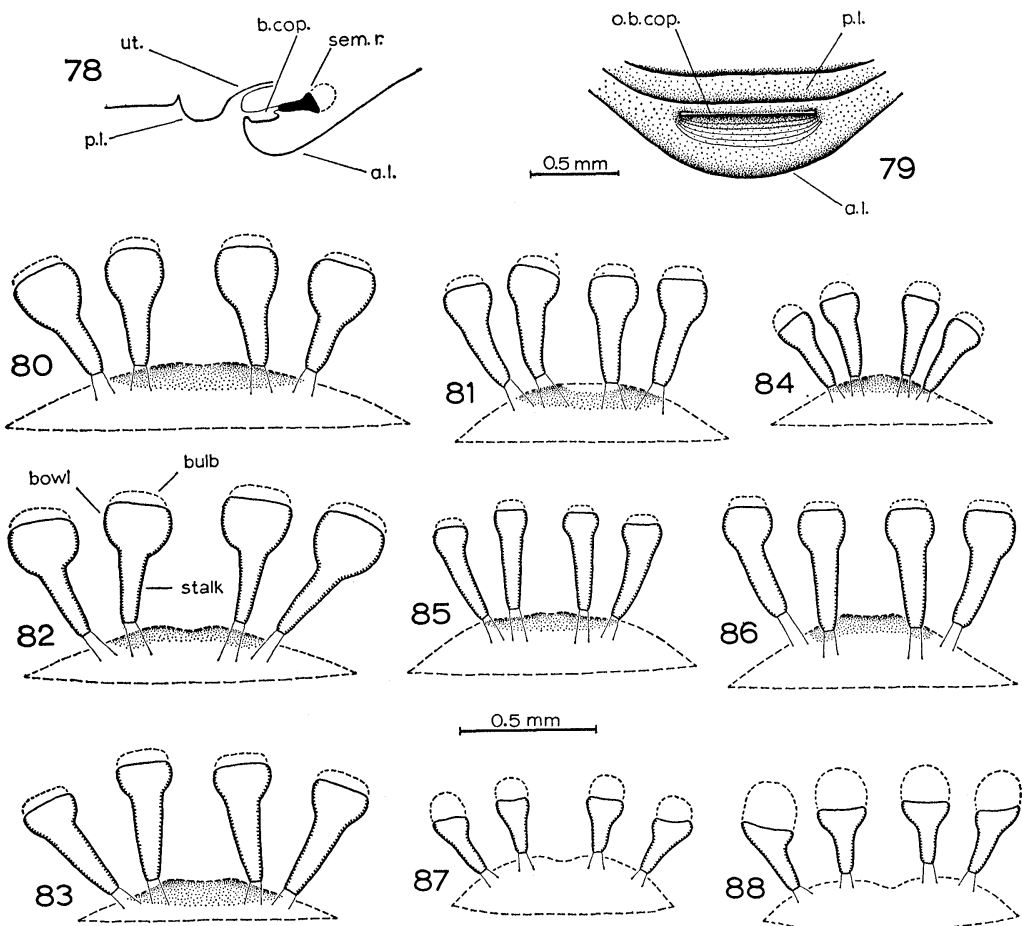

$0.5 \mathrm{~mm}$
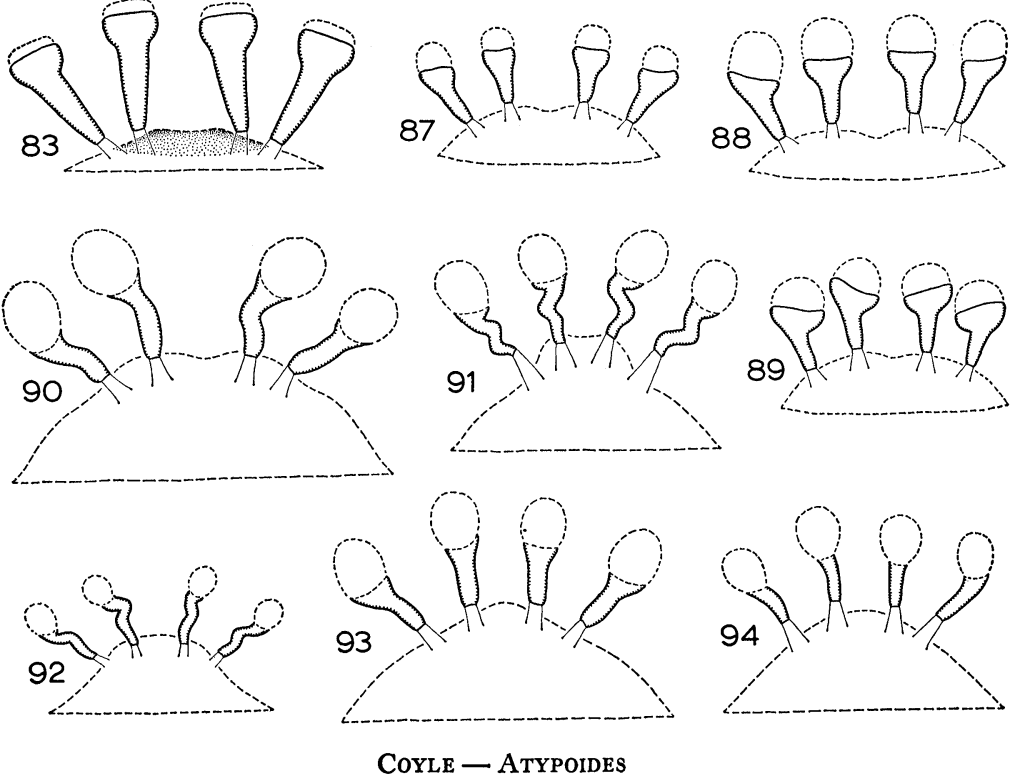
Metatarsus usually with 4 macrosetae -3 ventral, and I prolateral at distal end - positioned as in Figure 7I. Metatarsus not greatly elongate, bowed so that prolateral surface is concave; proximal half swollen in lateral view. Abdomen: 2 large tergites (second larger than first) and usually a bilateral pair of small sclerotized patches post. to second tergite. Spinnerets: (Fig. 32). AL without spigots, almost $\mathrm{I} / 2$ as long as PM. PM slightly expanded distally, maximum diam. I/ 3 to $\mathrm{I} / 2$ its length. Coloration: Pars thoracica pale yellow to tan. Pars cephalica light brown to brown. Sternum similar to pars thoracica; labium and palpal coxa similar to pars cephalica. Chelicerae reddish brown to very dark reddish brown. Pedipalps pale grayish orange to orange brown dorsally. Leg I orange to bright orange brown, darkest dorsally. Rest of legs duller, dorsally similar to pars thoracica, ventrally lighter. Abdomen very light grayish yellow, tergites darker yellowish gray. Holotype at lighter end of range.

Female. Carapace: (Figs. 4, 5, I8). Quite broad. Shape and position of thoracic groove and distribution of setae similar to that in male. Pars cephalica very strongly elevated, highest just behind eye group. Height of clypeus at ALE I/2 to I times the vertical diam. of ALE. Diam. of AME slightly less or equal to their distance apart. Sternum: (Fig. 38). As wide as long. Shape and position of sigilla similar to that in male. Numerous stout, sharp sternal setae as well as long slender ones. Chelicerae: (Figs. 4, 5, 43). Very robust. Dorsal protuberance broadly rounded in side view. Microteeth positioned beside last 2 or last macrotooth and extend post. to last macrotooth. Wide seta-less area on ectal side of ant. half of macrotooth row. Abdomen: Single large tergite corresponding to second tergite on male. Ant. to this is bilateral pair of prominent setae sometimes with tiny sclerotized patches at bases corresponding to first tergite of male. Spinnerets: (Fig. 32). Slightly thicker than in males, but length ratios similar. AL without spigots. PM slightly expanded distally, maximum diam. about I/2 length. Genitalia: (Figs. 78, 79, 87-89). Seminal receptacles with short, rather stout, straight to slightly curved stalk, wide prominent bowl. Coloration: Pars cephalica light brown; pars thoracica slightly paler. Sternum similar to pars cephalica; labium and palpal coxae darker brown. Chelicerae brown. Pedipalps and legs dorsally similar to pars thoracica (except tarsi of pedipalps and of leg I darker), lighter ventrally. Abdomen and tergite as in male.

DIAGNosis. Both sexes of $A$. hadros can be easily distinguished from the other species by the very wide sternum (Figs. 37, 38), 
which difference is expressed by SL/SW for the females in Table II. The slight expansion of the posterior portion of the thoracic groove and the more posterior placement of the thoracic groove aid in identification. Males. The palpus structure (Fig. 57) and the shapes and macrosetae distribution patterns of the tibia and the metatarsus of leg I (Figs. 7I-73) are distinctive for this species. The small value of IML for $A$. hadros separates it from the other species (Table I). The shortness of both tibia and metatarsus of leg IV allows separation from the other species by IVTL/CL and IVML/ CL (Table I). The stiff non-attenuate setae forming the posterior half of the cheliceral apophysis and the form of the apophysis (Fig. 46) helps to identify this species. Females. The wide seta-less area on the ectal side of the anterior half of the cheliceral macrotooth row is not found in the other species. The small number of IMS and CMT and the related ratio IVMCR/IMS (Table II) allow easy separation from the other species. PCT number (Table II) aids in di tingu shing $A$. hadros from $A$. gertschi. Metatarsus I is relatively short (see IML/CL and IFL/IML, Table II) and also aids in identification.

variation. Males. The two specimens from Ferne Clyffe St. Pk. are much smaller than the average size of the 15 males from Pine Hills. The characters which show the most geographic variation are $\mathrm{CAT} / \mathrm{CL}$ and PTL/CL. The cheliceral apophysis is thicker relative to body size in all Pine Hills males, and the palpal tibia is relatively longer in the Ferne Clyffe St. Pk. males. Considerable intrapopulation variation exists in macrosetae number and placement on leg I; the group on the retrolateral aspect of the ventral surface at the proximal end of the tibia contains from 2 to 7 macrosetae ( $\mathrm{I}$ to 4 enciform macrosetae) and the prolateral group contains from 4 to 15 macrosetae (4 to 14 enciform macrosetae). Figure 73 illustrates a tibia with high numbers in each group of macrosetae. The left metatarsus I of 12 of the 15 males has 4 macrosetae positioned as in Figure 7r. In two specimens the distal prolateral macroseta is absent, and in one only this macroseta and the most proximal one are present.

Females. The seminal receptacles of the three females are illustrated to show the variation in the prominence of the bowl. Figure 89 has large bowls which are distinct from the stalks, Figure 88 has slightly less prominent bowls, and Figure 87 has smaller bowls less clearly distinct from the stalks.

Distribution. Southern Illinois and eastern Missouri (Map i). 
Records. Illinois. Jackson Co.: Little Grand Canyon, about 5 mi. W. of Pomona, I2 Oct. 1967, 우 (J. A. Beatty). - Johnson Co.: Ferne Clyffe St. Pk., I3-14 Sept. I966, $20^{\star}$, 5ㅇ (FAC). Union Co.: Pine Hills, about $3 \mathrm{mi}$. N.E. of Aldridge, 7-I 4 Oct.

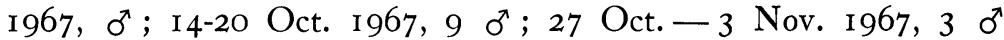
(J. Nelson). missouri. Dent Co.: Montauk St. Pk., I 2 Sept. 1966 (FAC).

\section{BANKS, N.}

\section{Literature Cited}

1896. New Californian spiders. Jour. New York Ent. Soc. 4(4) : 88-91. Сомsтоск, J.H.

1912. The Spider Book. New York. 721 pp.

1940. op. cit., rev. ed., Ithaca, N. Y. 729 pp.

Pickard-CAMBridge, O.

1883. On some new genera and species of spiders. Proc. Zool. Soc. Lond. pp. 352-365.

RIVERS, J. J.

1891. Description of the nest of the Californian turret building spider, with some references to allied species. Zoe 2: 318-320.

Simon, E.

1890. Liste des espèces de la famille des Aviculariides qui habitent l'Amérique du Nord. Actes Soc. Linn. Bord. 44: 307-339.

SMITH, C. P.

1908. A preliminary study of the Araneae Theraphosae of California.

Ann. Ent. Soc. Amer. 1(4) : 207-249.

\section{Appendix}

Abbreviations and definitions of measurements and meristic characters used in this study.

CL Maximum length of carapace (between lines tangent to anteriormost and posterior-most parts of carapace) along line parallel to median longitudinal axis, with lateral border of carapace horizontal.

CW Maximum width of carapace along line perpendicular to median longitudinal axis.

IFL Length of femur I taken as length of straight line connecting the proximal and distal points of articulation. All leg and pedipalp segment length measurements were made in side view along retrolateral surface of appendages after removing them from spider.

ITL Length of tibia I taken as length of straight line connecting proximal and distal points of articulation.

IML Length of metatarsus I taken as length of straight line connecting proximal point of articulation with distal-most point of segment.

ITarL Length of tarsus I taken as length of straight line connecting most proximal exposed point of tarsus with distal-most point of dorsal surface.

IVFL, IVTL, IVML, IVTarL Leg IV segment lengths measured in same manner as corresponding leg I segments. 
PFL Length of palpal femur measured same as IFL.

PTL Length of palpal tibia measured same as ITL.

PTT Maximum diameter of proximal half of palpal tibia perpendicular to line defined by PTL.

SL Maximum length of sternum on line parallel to median longitudinal axis. Anterior border of sternum is its pointed anterior extension lateral to labium.

SW Maximum width of sternum perpendicular to line defined by SL.

OQW Maximum width of eye group (ocular quadrangle) on line perpendicular to median longitudinal axis of carapace. All eye measurements are made in dorsal view with lateral border of carapace horizontal.

ALS Minimum distance between anterior lateral eyes.

ALD Maximum diameter of left anterior lateral eye.

AMS Minimum distance between pupils (light colored saucer-shaped central area of eye) of anterior median eyes.

AMD Transverse diameter of left anterior median eye pupil.

CAT Cheliceral apophysis thickness taken as diameter at midpoint of apophysis in lateral view,

CT Number of cheliceral macroteeth (per chelicera), the large teeth forming main tooth row on chelicera (Fig. 41).

CMT Number of cheliceral microteeth (per chelicera), the much smaller teeth scattered on ectal side of macrotooth row (Fig. 41).

PCT Number of teeth on claw of female pedipalp. All claw tooth counts include even the reduced proximal teeth. Counts must be made carefully under high magnification in strong light.

ICTP Number of teeth on prolateral claw of left tarsus I.

ICTR Number of teeth on retrolateral claw of left tarsus I.

IVCTP Number of teeth on prolateral claw of left tarsus IV.

IVCTR Number of teeth on retrolateral claw of left tarsus IV.

PTSP Number of enciform macrosetae on prolateral surface of tarsus of female pedipalp.

PTSR Number of enciform macrosetae on retrolateral surface of tarsus of female pedipalp.

IMS Number of enciform macrosetae on metatarsus of left leg I of female.

IVMT Number of trichobothia in row on dorsal surface of metatarsus IV.

IVMCR Number of setae in large comb on retrolateral surface at distal end of metatarsus IV.

EGS Number of epiandrous gland spigots. These are located just anterior to genital opening on abdomen of adult males. 
Table I. Measurements, meristic characters, and diagnostic ratios for adult males of each species of Atypoides. Figures represent range, mean, and standard deviation in $\mathrm{mm}$. Range and mode given for meristic characters.

\begin{tabular}{|c|c|c|c|c|c|c|c|}
\hline & riversi & gertschi & hadros & & riversi & gertschi & hadros \\
\hline $\mathrm{N}$ & 25 & 20 & 15 & $\mathrm{CAT}$ & $\begin{array}{l}0.43-0.69 \\
0.528 \pm .061\end{array}$ & $\begin{array}{l}0.65-1.27 \\
1.007 \pm .165\end{array}$ & $\begin{array}{l}0.63-1.01 \\
0.845 \pm .103\end{array}$ \\
\hline CL & $\begin{array}{l}4.6-5.8 \\
5.11 \pm .36\end{array}$ & $\begin{array}{c}5.8-8.2 \\
7.07 \pm .70\end{array}$ & $\begin{array}{l}4.0-5.0 \\
4.52 \pm .31\end{array}$ & ICTP & $\begin{array}{c}7-12 \\
(9)\end{array}$ & $\begin{array}{l}8-13 \\
(10)\end{array}$ & $\begin{array}{l}5-7 \\
(6)\end{array}$ \\
\hline $\mathrm{CW}$ & $\begin{array}{l}3.65-4.59 \\
4.075 \pm .271\end{array}$ & $\begin{array}{l}4.59-6.67 \\
5.628 \pm .553\end{array}$ & $\begin{array}{l}3.31-4.07 \\
3.775 \pm .241\end{array}$ & ICTR & $\begin{array}{l}6-11 \\
(8,9)\end{array}$ & $\begin{array}{l}8-11 \\
(10)\end{array}$ & $\begin{array}{l}4-7 \\
(6)\end{array}$ \\
\hline IFL & $\begin{array}{l}4.22-5.69 \\
4.845 \pm .443\end{array}$ & $\begin{array}{l}5.39-7.50 \\
6.538 \pm .684\end{array}$ & $\begin{array}{c}3.80-4.63 \\
4.156 \pm .243\end{array}$ & IVCTP & $\begin{array}{l}5-9 \\
(7)\end{array}$ & $\begin{array}{c}5-10 \\
(9)\end{array}$ & $\begin{array}{l}3-5 \\
(4)\end{array}$ \\
\hline ITL & $\begin{array}{l}3.09-3.95 \\
3.469 \pm .232\end{array}$ & $\begin{array}{l}3.69-4.97 \\
4.342 \pm .490\end{array}$ & $\begin{array}{c}2.48-3.05 \\
2.762 \pm .176\end{array}$ & IVCTR & $\begin{array}{c}6-12 \\
(7)\end{array}$ & $\begin{array}{c}5-11 \\
(8)\end{array}$ & $\begin{array}{l}3-5 \\
(4)\end{array}$ \\
\hline IML & $\begin{array}{l}4.14-5.73 \\
4.921 \pm .447\end{array}$ & $\begin{array}{l}.4 .82-6.78 \\
5.835 \pm .751\end{array}$ & $\begin{array}{l}2.94-3.58 \\
3.280 \pm .212\end{array}$ & EGS & $\begin{array}{c}26-50 \\
35.5\end{array}$ & $\begin{array}{l}37-87 \\
56.1\end{array}$ & $\begin{array}{c}11-26 \\
19.4\end{array}$ \\
\hline ITarL & $\begin{array}{l}2.14-3.27 \\
2.626 \pm .371\end{array}$ & $\begin{array}{l}2.33-2.94 \\
2.610 \pm .192\end{array}$ & $\begin{array}{l}1.54-2.03 \\
1.797 \pm .135\end{array}$ & IML & $0.86-1.04$ & $0.74-0.89$ & $0.69-0.76$ \\
\hline IVFL & $\begin{array}{l}4.03-5.61 \\
4.700 \pm .406\end{array}$ & $\begin{array}{l}5.16-7.69 \\
6.609 \pm .777\end{array}$ & $\begin{array}{l}3.24-3.99 \\
3.625 \pm .224\end{array}$ & $\begin{array}{l}\overline{\text { CL }} \\
\text { IVTL }\end{array}$ & $\begin{array}{l}0.961 \pm .045 \\
0.60-0.67\end{array}$ & $\begin{array}{c}0.823 \pm .047 \\
0.59-0.69\end{array}$ & $\begin{array}{c}0.726 \pm .024 \\
0.46-0.52\end{array}$ \\
\hline IVTL & $\begin{array}{l}2.86-3.84 \\
3.257 \pm .242\end{array}$ & $\begin{array}{c}3.80-5.42 \\
4.596 \pm .558\end{array}$ & $\begin{array}{c}1.96-2.45 \\
2.240 \pm .154\end{array}$ & $\begin{array}{l}\overline{\text { CL }} \\
\text { IVML }\end{array}$ & $\begin{array}{l}0.636 \pm .017 \\
0.91-1.03\end{array}$ & $\begin{array}{c}0.649 \pm .029 \\
0.98-1.14\end{array}$ & $\begin{array}{c}0.496 \pm .016 \\
0.65-0.80\end{array}$ \\
\hline IVML & $\begin{array}{l}4.33-5.61 \\
4.987 \pm .376\end{array}$ & $\begin{array}{c}6.10-8.70 \\
7.469 \pm .957\end{array}$ & $\begin{array}{l}3.12-3.80 \\
3.422 \pm .208\end{array}$ & $\begin{array}{l}\mathrm{CL} \\
\text { IVTarL }\end{array}$ & $\begin{array}{l}0.974 \pm .029 \\
0.61-0.71\end{array}$ & $\begin{array}{l}1.054 \pm .052 \\
0.48-0.55\end{array}$ & $\begin{array}{l}0.758 \pm .038 \\
0.51-0.59\end{array}$ \\
\hline IVTarL & $\begin{array}{l}3.01-3.99 \\
3.446 \pm .286\end{array}$ & $\begin{array}{c}3.12-4.29 \\
3.721 \pm .389\end{array}$ & $\begin{array}{l}2.29-2.78 \\
2.509 \pm .170\end{array}$ & $\begin{array}{l}\mathrm{CL} \\
\mathrm{OQW}\end{array}$ & $\begin{array}{l}0.673 \pm .026 \\
0.20-0.24\end{array}$ & $\begin{array}{l}0.526 \pm .020 \\
0.15-0.18\end{array}$ & $\begin{array}{l}0.555 \pm .021 \\
0.20-0.22\end{array}$ \\
\hline oQw & $\begin{array}{l}1.00-1.37 \\
1.167 \pm .100\end{array}$ & $\begin{array}{l}1.04-1.32 \\
1.178 \pm .083\end{array}$ & $\begin{array}{l}0.83-1.05 \\
0.967 \pm .069\end{array}$ & $\begin{array}{l}\mathrm{CL} \\
\mathrm{CL}\end{array}$ & $\begin{array}{l}0.228 \pm .011 \\
26.5-34.3\end{array}$ & $\begin{array}{l}0.167 \pm .012 \\
40.3-54.8\end{array}$ & $\begin{array}{l}0.214 \pm .006 \\
25.3-35.6\end{array}$ \\
\hline ALS & $\begin{array}{l}0.44-0.69 \\
0.565 \pm .062\end{array}$ & $\begin{array}{c}0.41-0.72 \\
0.558 \pm .079\end{array}$ & $\begin{array}{c}0.41-0.56 \\
0.484 \pm .047\end{array}$ & $\begin{array}{l}\overrightarrow{\mathrm{AMD}} \\
\mathrm{PTT}\end{array}$ & $\begin{array}{l}30.19 \pm 1.95 \\
0.22-0.26\end{array}$ & $\begin{array}{l}47.00 \pm 5.22 \\
0.15-0.17\end{array}$ & $\begin{array}{l}30.60 \pm 1.99 \\
0.24-0.27\end{array}$ \\
\hline ALD & $\begin{array}{l}0.24-0.41 \\
0.321 \pm .038\end{array}$ & $\begin{array}{c}0.27-0.35 \\
0.311 \pm .024\end{array}$ & $\begin{array}{l}0.24-0.30 \\
0.266 \pm .018\end{array}$ & $\overline{\mathrm{CL}}$ & $0.246 \pm .008$ & $0.163 \pm .006$ & $0.259 \pm .010$ \\
\hline AMS & $\begin{array}{l}0.11-0.20 \\
0.142 \pm .021\end{array}$ & $\begin{array}{c}0.12-0.22 \\
0.173 \pm .029\end{array}$ & $\begin{array}{l}0.09-0.13 \\
0.107 \pm .011\end{array}$ & $\frac{\mathrm{CAT}}{\mathrm{CL}}$ & $\begin{array}{l}0.07-0.12 \\
0.103 \pm .011\end{array}$ & $\begin{array}{c}0.11-0.17 \\
0.142 \pm .019\end{array}$ & $\begin{array}{c}0.15-0.20 \\
0.186 \pm .013\end{array}$ \\
\hline AMD & $\begin{array}{l}0.15-0.20 \\
0.170 \pm .014\end{array}$ & $\begin{array}{l}0.14-0.17 \\
0.151 \pm .011\end{array}$ & $\begin{array}{l}0.13-0.16 \\
0.148 \pm .009\end{array}$ & $\frac{\text { IFL }}{\text { IML }}$ & $\begin{array}{l}0.93-1.07 \\
0.985 \pm .043\end{array}$ & $\begin{array}{l}1.04-1.24 \\
1.125 \pm .054\end{array}$ & $\begin{array}{c}1.21-1.31 \\
1.268 \pm .028\end{array}$ \\
\hline PFL & $\begin{array}{l}2.94-4.07 \\
3.390 \pm .323\end{array}$ & $\begin{array}{l}4.44-5.84 \\
5.214 \pm .383\end{array}$ & $\begin{array}{l}2.97-3.54 \\
3.227 \pm .166\end{array}$ & $\frac{\text { IVML }}{\text { IML }}$ & $\begin{array}{l}0.95-1.07 \\
1.015 \pm .027\end{array}$ & $\begin{array}{c}1.22-1.34 \\
1.281 \pm .031\end{array}$ & $\begin{array}{c}0.93-1.11 \\
1.044 \pm .043\end{array}$ \\
\hline PTL & $\begin{array}{l}2.41-3.24 \\
2.759 \pm .282\end{array}$ & $\begin{array}{l}3.12-4.18 \\
3.630 \pm .293\end{array}$ & $\begin{array}{l}2.45-2.86 \\
2.602 \pm .113\end{array}$ & $\frac{\text { IVML }}{\text { IVTarL }}$ & $\begin{array}{l}1.36-1.53 \\
1.449 \pm .049\end{array}$ & $\begin{array}{l}1.86-2.21 \\
2.003 \pm .087\end{array}$ & $\begin{array}{l}1.20-1.42 \\
1.365 \pm .054\end{array}$ \\
\hline PTT & $\begin{array}{c}1.11-1.41 \\
1.259 \pm .084\end{array}$ & $\begin{array}{l}1.00-1.29 \\
1.146 \pm .089\end{array}$ & $\begin{array}{l}1.05-1.25 \\
1.169 \pm .060\end{array}$ & $\frac{\text { PTT }}{\text { PTL }}$ & $\begin{array}{l}0.32-0.50 \\
0.458 \pm .030\end{array}$ & $\begin{array}{l}0.30-0.33 \\
0.316 \pm .008\end{array}$ & $\begin{array}{l}0.42-0.47 \\
0.449 \pm .013\end{array}$ \\
\hline
\end{tabular}


Table II. Measurements, meristic characters, and diagnostic ratios for adult females of each species of Atypoides. Figures represent range, mean, and standard deviation in $\mathrm{mm}$. Range and mode given for meristic characters. Number of "reproductively active" females in parentheses after $\mathrm{N}$.

\begin{tabular}{|c|c|c|c|c|c|c|c|}
\hline & riversi & gertschi & hadros & & riversi & gerlschi & hadros \\
\hline $\mathbf{N}$ & $86(30)$ & $57(1)$ & $6(5)$ & PCT & $\begin{array}{l}1-7 \\
(5)\end{array}$ & $\begin{array}{l}3-10 \\
(5,6)\end{array}$ & $\begin{array}{l}0-2 \\
(2)\end{array}$ \\
\hline$C L$ & $\begin{array}{l}5.0-7.8 \\
6.08 \pm .55\end{array}$ & $\begin{array}{c}6.5-9.0 \\
7.44 \pm .64\end{array}$ & $\begin{array}{l}4.5-6.2 \\
5.07 \pm .63\end{array}$ & ICTP & $6-12$ & $(3,0)$ & $4-5$ \\
\hline cw & $\begin{array}{l}3.84-6.40 \\
4.793 \pm .491\end{array}$ & $\begin{array}{l}4.82-6.86 \\
5.635 \pm .517\end{array}$ & $\begin{array}{l}3.77-5.27 \\
4.357 \pm .554\end{array}$ & \multirow[t]{2}{*}{ ICTR } & \multirow{2}{*}{$\begin{array}{c}7-10 \\
(8)\end{array}$} & $\begin{array}{c}(9) \\
5-12\end{array}$ & \multirow{2}{*}{$\begin{array}{c}4-5 \\
(5)\end{array}$} \\
\hline IFL & $\begin{array}{l}3.88-6.67 \\
4.913 \pm .529\end{array}$ & $\begin{array}{l}5.20-7.08 \\
5.867 \pm .479\end{array}$ & $\begin{array}{l}3.16-4.26 \\
3.507 \pm .433\end{array}$ & & & $\begin{array}{c}5-12 \\
(9)\end{array}$ & \\
\hline ITLL & $\begin{array}{l}2.41-4.44 \\
3.140 \pm .378\end{array}$ & $\begin{array}{c}3.12-4.41 \\
3.588 \pm .323\end{array}$ & $\begin{array}{c}1.77-2.45 \\
2.025 \pm .251\end{array}$ & IVCTP & $\begin{array}{c}5-11 \\
(7)\end{array}$ & $\begin{array}{c}5-10 \\
(7)\end{array}$ & $\begin{array}{c}2-4 \\
(3)\end{array}$ \\
\hline IML & $\begin{array}{l}2.71-4.97 \\
3.427 \pm .400\end{array}$ & $3.54-5.08$ & $1.65-2.33$ & 1) & (7) & $\begin{array}{c}4-10 \\
(8)\end{array}$ & $\begin{array}{l}3-4 \\
(3,4)\end{array}$ \\
\hline ITarL & $\begin{array}{l}3.427 \pm .400 \\
1.20-1.80\end{array}$ & $\begin{array}{l}4.109 \pm .409 \\
1.43-1.80\end{array}$ & $\begin{array}{l}1.917 \pm .244 \\
0.82-1.09\end{array}$ & P'TSP & $\begin{array}{c}8-21 \\
(12)\end{array}$ & $\begin{array}{c}7-12 \\
(8)\end{array}$ & $\begin{array}{l}8-12 \\
(8,9)\end{array}$ \\
\hline IVFL, & $\begin{array}{l}1.439 \pm .129 \\
3.27-5.88\end{array}$ & $\begin{array}{l}1.616 \pm .094 \\
5.20-7.16\end{array}$ & $\begin{array}{l}0.923 \pm .104 \\
3.01-4.14\end{array}$ & PTSR & $\begin{array}{c}4-11 \\
(6)\end{array}$ & $\begin{array}{l}3-6 \\
(4)\end{array}$ & $\begin{array}{c}4-6 \\
(5)\end{array}$ \\
\hline IVTL & $\begin{array}{l}4.339 \pm .439 \\
2.14-3.84\end{array}$ & $\begin{array}{l}5.922 \pm .529 \\
2.94-4.67\end{array}$ & $\begin{array}{l}3.412 \pm .434 \\
1.58-2.22\end{array}$ & IMS & $\begin{array}{c}17-32 \\
(22)\end{array}$ & $\begin{array}{c}18-35 \\
(25)\end{array}$ & $\begin{array}{c}8-10 \\
(8)\end{array}$ \\
\hline IVML & $\begin{array}{l}2.790 \pm .298 \\
2.90-5.39\end{array}$ & $\begin{array}{l}3.769 \pm .397 \\
4.71-6.93\end{array}$ & $\begin{array}{l}1.823 \pm .229 \\
2.37-3.09\end{array}$ & IVMT & $\begin{array}{c}9-20 \\
(13,14)\end{array}$ & $\begin{array}{c}11-26 \\
(12)\end{array}$ & $\begin{array}{c}9-13 \\
(9)\end{array}$ \\
\hline IVTarL & $\begin{array}{l}3.838 \pm .388 \\
1.24-1.96\end{array}$ & $\begin{array}{l}5.743 \pm .587 \\
1.80-2.29\end{array}$ & $\begin{array}{l}2.615 \pm .285 \\
0.98-1.28\end{array}$ & IVMCR & $\begin{array}{c}5-10 \\
(7)\end{array}$ & $\begin{array}{l}4-8 \\
(6)\end{array}$ & $\begin{array}{r}8-9 \\
(8,9)\end{array}$ \\
\hline & $1.549 \pm .121$ & $2.011 \pm .129$ & $1.077 \pm .112$ & IML & $0.51-0.65$ & $0.50-0.59$ & $0.36-0.38$ \\
\hline SL & $\begin{array}{l}2.94-4.93 \\
3.762 \pm .394\end{array}$ & $\begin{array}{c}3.88-5.42 \\
4.508+429\end{array}$ & $\begin{array}{l}2.63-3.69 \\
3.075+389\end{array}$ & $\overline{\mathrm{CL}}$ & $0.563 \pm .028$ & $0.552 \pm .022$ & $0.377 \pm .008$ \\
\hline & $3.762 \pm .394$ & $4.508 \pm .429$ & $3.075 \pm .389$ & ITarL & $0.21-0.25$ & $0.19-0.24$ & $0.17-0.18$ \\
\hline sw & $\begin{array}{l}2.33-3.95 \\
2.826 \pm .241\end{array}$ & $\begin{array}{c}2.78-3.92 \\
3.237 \pm .297\end{array}$ & $\begin{array}{c}2.71-3.73 \\
3.105 \pm .384\end{array}$ & & $0.237 \pm .009$ & $0.218 \pm .012$ & $0.182 \pm .013$ \\
\hline & & & & IVML & $0.55-0.70$ & $0.70-0.86$ & $0.50-0.53$ \\
\hline OQW & $\begin{array}{l}1.14-1.96 \\
1.428 \pm .142\end{array}$ & $\begin{array}{c}1.07-1.36 \\
1.224 \pm .085\end{array}$ & $\begin{array}{l}1.06-1.37 \\
1.190 \pm .104\end{array}$ & & $0.631 \pm .027$ & $0.772 \pm .040$ & $0.516 \pm .013$ \\
\hline ALS & $\begin{array}{l}0.49-1.02 \\
0.675 \pm .097\end{array}$ & $\begin{array}{c}0.47-0.69 \\
0.551 \pm .050\end{array}$ & $\begin{array}{c}0.52-0.74 \\
0.630 \pm .070\end{array}$ & $\frac{\mathrm{OQW}}{\mathrm{CL}}$ & $\begin{array}{l}0.21-0.26 \\
0.235 \pm .013\end{array}$ & $\begin{array}{l}0.13-0.19 \\
0.165 \pm .013\end{array}$ & $\begin{array}{l}0.22-0.25 \\
0.235 \pm .013\end{array}$ \\
\hline ALD & $\begin{array}{l}0.29-0.46 \\
0.369 \pm .036\end{array}$ & $\begin{array}{l}0.22-0.38 \\
0.326 \pm .034\end{array}$ & $\begin{array}{l}0.27-0.30 \\
0.285 \pm .014\end{array}$ & $\frac{\text { CL }}{A M D}$ & $\begin{array}{l}29.0-43.9 \\
34.37 \pm 3.03\end{array}$ & $\begin{array}{l}46.7-66.5 \\
55.37 \pm 5.64\end{array}$ & $\begin{array}{l}31.6-37.5 \\
35.92 \pm 2.16\end{array}$ \\
\hline AMS & $\begin{array}{l}0.13-0.25 \\
0.183 \pm .025\end{array}$ & $\begin{array}{c}0.14-0.25 \\
0.182 \pm .025\end{array}$ & $\begin{array}{c}0.13-0.17 \\
0.155 \pm .016\end{array}$ & $\frac{\text { IFL }}{\text { IML }}$ & $\begin{array}{l}1.33-1.52 \\
1.436 \pm .048\end{array}$ & $\begin{array}{l}1.36-1.52 \\
1.431 \pm .045\end{array}$ & $\begin{array}{l}1.77-1.91 \\
1.831 \pm .047\end{array}$ \\
\hline AMD & $\begin{array}{l}0.12-0.22 \\
0.178 \pm .021\end{array}$ & $\begin{array}{c}0.11-0.16 \\
0.135 \pm .013\end{array}$ & $\begin{array}{c}0.12-0.17 \\
0.142 \pm .018\end{array}$ & $\frac{\text { IVML }}{\text { IML }}$ & $\begin{array}{l}1.03-1.20 \\
1.123 \pm .043\end{array}$ & $\begin{array}{l}1.34-1.45 \\
1.398 \pm .038\end{array}$ & $\begin{array}{l}1.32-1.43 \\
1.367 \pm .038\end{array}$ \\
\hline CT & $\begin{array}{l}9-16 \\
(10)\end{array}$ & $\begin{array}{l}9-16 \\
(11)\end{array}$ & $\begin{array}{c}10-13 \\
(10)\end{array}$ & $\frac{\text { SL }}{\text { SW }}$ & $\begin{array}{l}1.21-1.45 \\
1.330 \pm .060\end{array}$ & $\begin{array}{l}1.29-1.49 \\
1.393 \pm .046\end{array}$ & $\begin{array}{l}0.96-1.02 \\
0.990 \pm .023\end{array}$ \\
\hline CMT & $\begin{array}{l}6-33 \\
(18)\end{array}$ & $\begin{array}{c}9-26 \\
(18,19)\end{array}$ & $\begin{array}{c}2-5 \\
(3)\end{array}$ & $\frac{\text { IVMCR }}{\text { IMS }}$ & $\begin{array}{l}0.21-0.46 \\
0.328 \pm .056\end{array}$ & $\begin{array}{l}0.17-0.33 \\
0.255 \pm .043\end{array}$ & $\begin{array}{l}0.80-1.10 \\
0.990 \pm .129\end{array}$ \\
\hline
\end{tabular}


Table III. Measurements and meristic character values for the type specimens of the species of Atypoides. Measurements in $\mathrm{mm}$.

\begin{tabular}{llll|llcc} 
& $\begin{array}{c}\text { riversi } \\
\text { (lecto- } \\
\text { type) }\end{array}$ & $\begin{array}{c}\text { gertschi } \\
\text { (holo- } \\
\text { type) }\end{array}$ & $\begin{array}{c}\text { hadros } \\
\text { (holo- } \\
\text { type) }\end{array}$ & & $\begin{array}{c}\text { riversi } \\
\text { (lecto- } \\
\text { type) }\end{array}$ & $\begin{array}{c}\text { gertschi } \\
\text { (holo- } \\
\text { type) }\end{array}$ & $\begin{array}{c}\text { hadros } \\
\text { (holo- } \\
\text { type) }\end{array}$ \\
\hline CL & 5.5 & 7.0 & 4.0 & ALD & 0.35 & 0.27 & 0.28 \\
CW & 4.29 & 5.35 & 3.31 & AMS & 0.16 & 0.13 & 0.11 \\
IFL & 5.35 & 6.40 & 3.80 & AMD & 0.16 & 0.14 & 0.14 \\
ITL & 3.58 & 4.29 & 2.48 & PFL & 3.69 & 5.08 & 3.01 \\
IML & 5.01 & 5.95 & 2.94 & PTL & 3.05 & 3.54 & 2.45 \\
ITarL & 3.05 & 2.63 & 1.58 & PTT & 1.36 & 1.09 & 1.05 \\
IVFL & 5.05 & 6.48 & 3.24 & CAT & 0.59 & 0.95 & 0.66 \\
IVTL & 3.46 & 4.44 & 1.96 & ICTP & 8 & 10 & 7 \\
IVML & 5.24 & 7.27 & 3.16 & ICTR & 8 & 10 & 6 \\
IVTarL & 3.65 & 3.54 & 2.29 & IVCTP & 5 & 9 & 4 \\
OQW & 1.24 & 1.07 & 0.83 & IVCTR & 7 & 9 & 4 \\
ALS & 0.60 & 0.55 & 0.44 & EGS & 28 & 57 & 13 \\
\hline
\end{tabular}



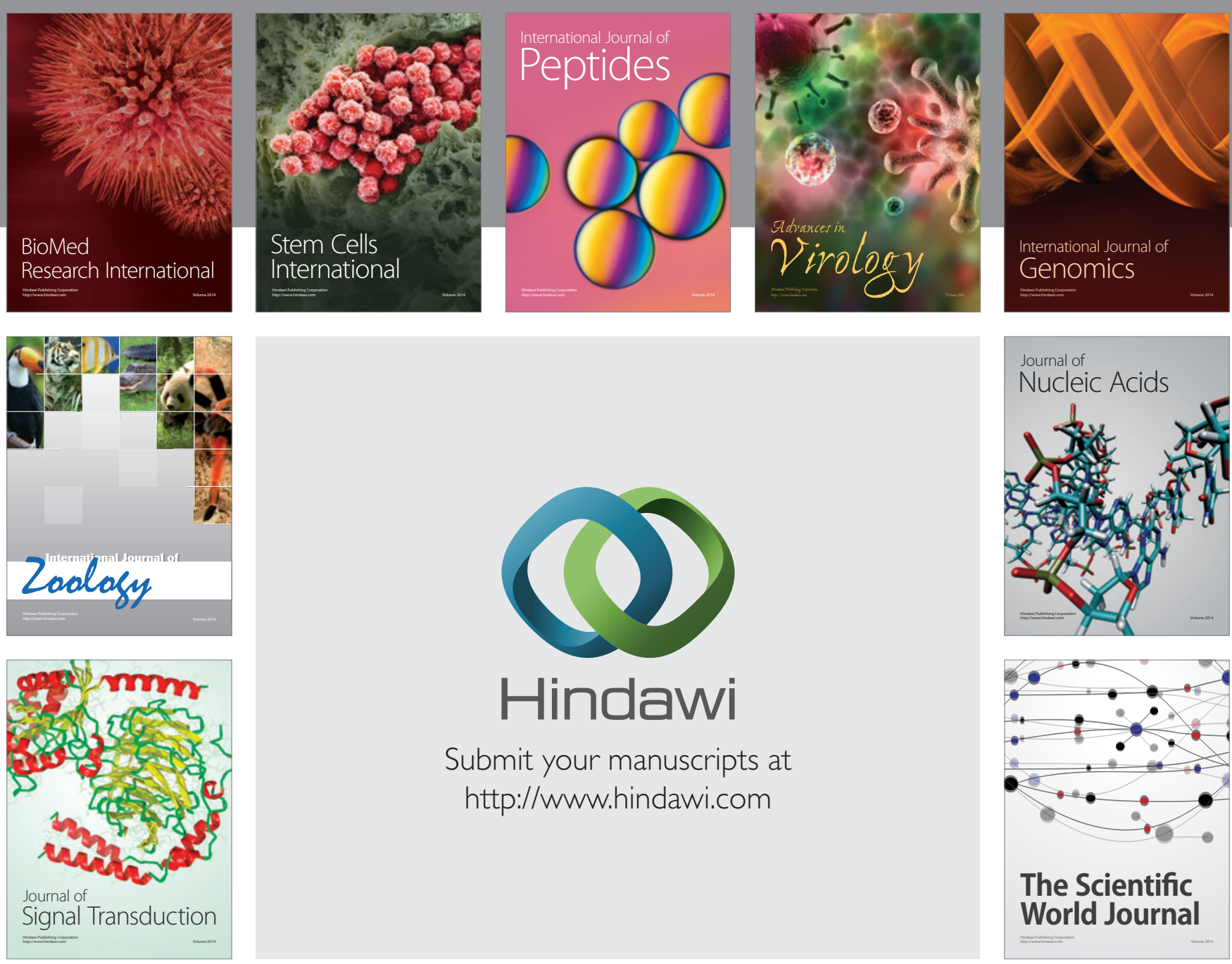

Submit your manuscripts at

http://www.hindawi.com
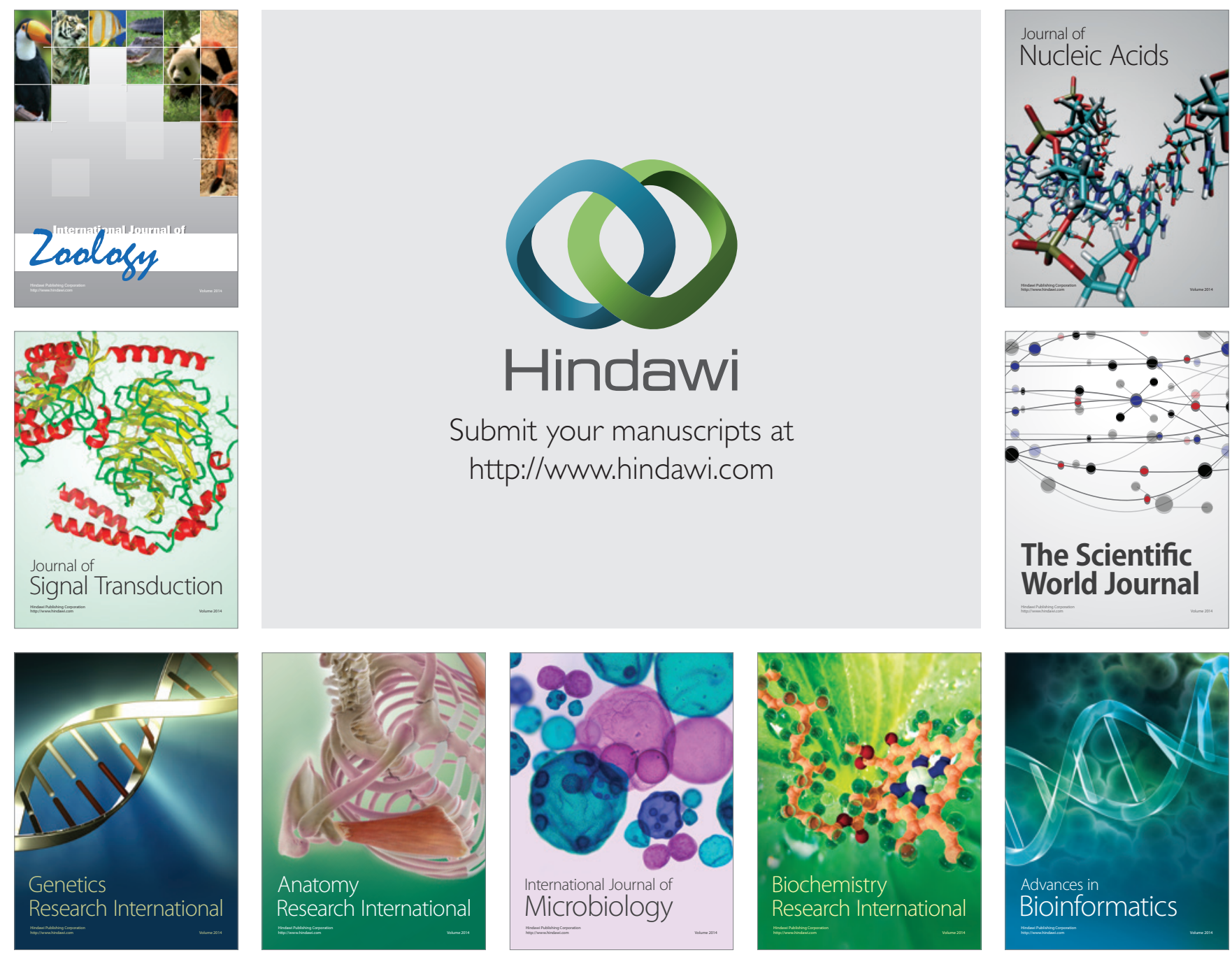

The Scientific World Journal
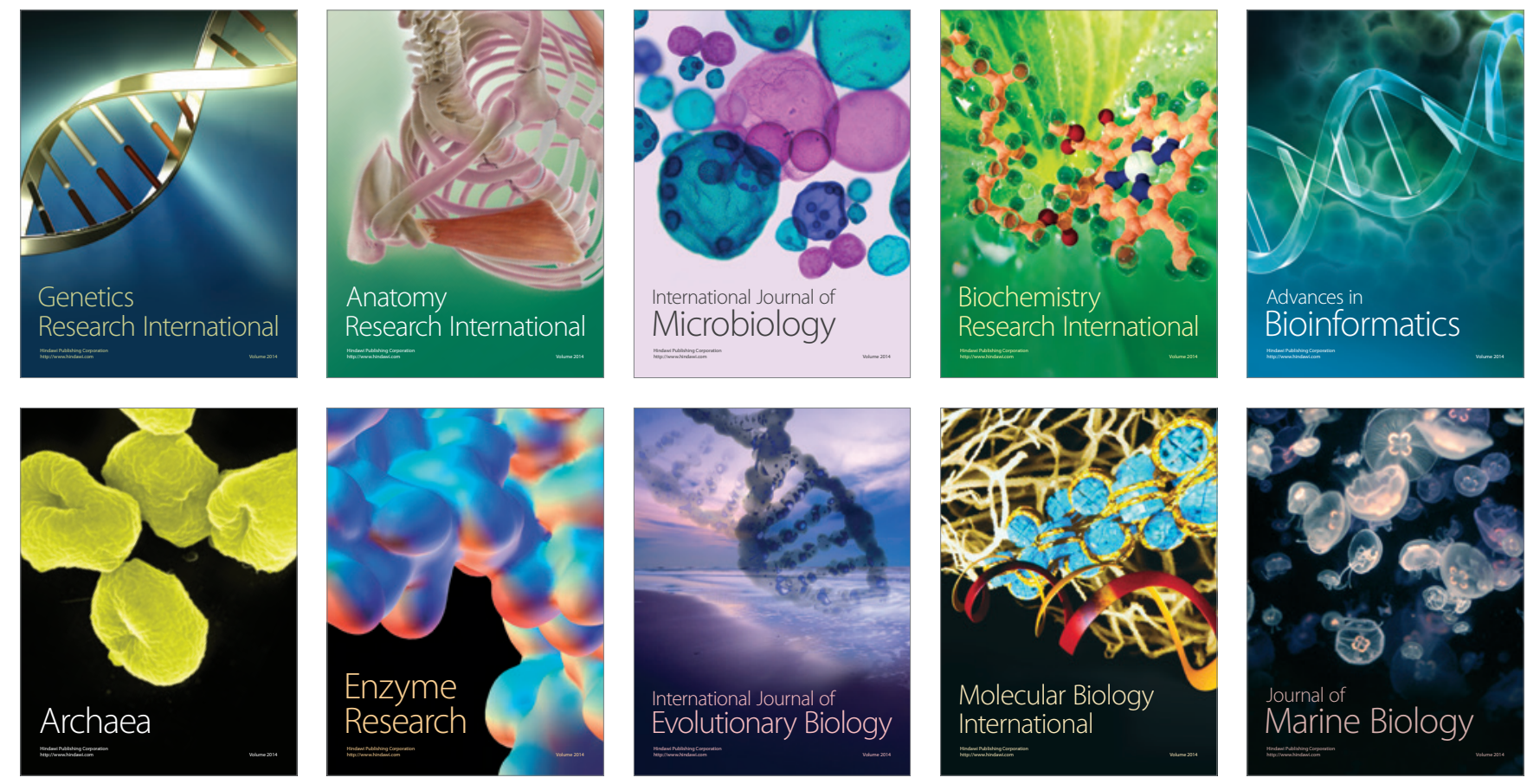